\title{
The Impact of Glucose-Lowering Drugs on Sarcopenia in Type 2 Diabetes: Current Evidence and Underlying Mechanisms
}

\author{
Elena Massimino, Anna Izzo, Gabriele Riccardi and Giuseppe Della Pepa *(D) \\ Department of Clinical Medicine and Surgery, Federico II University, Via Sergio Pansini 5, 80131 Naples, Italy; \\ elenamassimino@libero.it (E.M.); ariannaizzo.1991@gmail.com (A.I.); riccardi@unina.it (G.R.) \\ * Correspondence: giuseppe.dellapepa@unina.it; Tel.: +39-081-746-2166
}

check for updates

Citation: Massimino, E.; Izzo, A.; Riccardi, G.; Della Pepa, G. The Impact of Glucose-Lowering Drugs on Sarcopenia in Type 2 Diabetes: Current Evidence and Underlying Mechanisms. Cells 2021, 10, 1958. https://doi.org/10.3390/cells10081958

Academic Editor: Antonio Musarò

Received: 30 June 2021

Accepted: 29 July 2021

Published: 1 August 2021

Publisher's Note: MDPI stays neutral with regard to jurisdictional claims in published maps and institutional affiliations.

Copyright: (c) 2021 by the authors. Licensee MDPI, Basel, Switzerland. This article is an open access article distributed under the terms and conditions of the Creative Commons Attribution (CC BY) license (https:// creativecommons.org/licenses/by/ $4.0 /)$.

\begin{abstract}
The age-related decrease in skeletal muscle mass together with the loss of muscle power and function is defined sarcopenia. Mounting evidence suggests that the prevalence of sarcopenia is higher in patients with type 2 diabetes mellitus (T2DM), and different mechanisms may be responsible for this association such as impaired insulin sensitivity, chronic hyperglycemia, advanced glycosylation end products, subclinical inflammation, microvascular and macrovascular complications. Glucose-lowering drugs prescribed for patients with T2DM might impact on these mechanisms leading to harmful or beneficial effect on skeletal muscle. Importantly, beyond their glucose-lowering effects, glucose-lowering drugs may affect per se the equilibrium between protein anabolism and catabolism through several mechanisms involved in skeletal muscle physiology, contributing to sarcopenia. The aim of this narrative review is to provide an update on the effects of glucose-lowering drugs on sarcopenia in individuals with T2DM, focusing on the parameters used to define sarcopenia: muscle strength (evaluated by handgrip strength), muscle quantity/quality (evaluated by appendicular lean mass or skeletal muscle mass and their indexes), and physical performance (evaluated by gait speed or short physical performance battery). Furthermore, we also describe the plausible mechanisms by which glucose-lowering drugs may impact on sarcopenia.
\end{abstract}

Keywords: glucose-lowering drugs; type 2 diabetes mellitus; sarcopenia; skeletal muscle index; skeletal muscle mass

\section{Introduction}

The improvement of healthcare systems and the advancements in the prevention and treatment of major non communicable illnesses, together to the economic and social development, have substantially increased the longevity of the population worldwide.

In 2020, there were 727 million persons aged 65 years or over in the global population. This number is projected to double to 1.5 billion in 2050. Globally, the share of the population aged 65 years or over is expected to increase from $9.3 \%$ in 2020 to $16 \%$ in 2050 [1].

Although population aging may represent a human success story, it is widely known that aging is associated with a physiological impairment in all areas of the body. Many changes and dysfunctions also occur in skeletal muscle. In fact, a progressive and generalized loss of muscle mass can be observed after the age of 40 years; the rate of deterioration has been estimated to be $8 \%$ every 10 years up to 70 years, and 15-25\% every 10 years after this age [2]. Similarly, a 10-15\% loss of leg strength every 10 years has been reported to occur up to 70 years, increasing to $25-40 \%$ every 10 years after this age [3].

These age-related changes in skeletal muscle make up an independent condition termed sarcopenia, now recognized by the International Classification of Disease, Tenth Revision, Clinical Modification (ICD-10-CM), code (i.e., M 62.84) [4]. Sarcopenia is defined as a syndrome in which muscle mass and muscle function (muscle strength and/or physical performance) progressively decrease with age $[5,6]$. Sarcopenia diagnosis is established by the 
presence of low muscle quantity or quality. When low muscle quantity/quality, low muscle strength, and low physical performance are all detected, sarcopenia is considered severe.

The age-related changes involved in sarcopenia not only affect the upper and lower limbs, but rather involve a decline in mass and strength of the respiratory muscles configuring the recent term of "respiratory sarcopenia" [7]. Respiratory sarcopenia is characterized as whole-body sarcopenia with low respiratory muscle mass followed by low respiratory muscle strength and/or deteriorated respiratory function [8]. Various factors may lead to respiratory sarcopenia such as aging, inactivity, undernutrition, diseases, inflammation, and cachexia [8]. The diaphragm is the primary muscle of the respiratory pump, and reduced diaphragm muscle mass impairs inspiratory strength and cough function [8]. The reduction in respiratory muscle function in the elderly makes this population more vulnerable to disease and disability [6,9], and contributes to respiratory complications, a common cause of morbidity and mortality in the elderly [10,11].

A wide variety of tests and tools are now available for the characterization of sarcopenia; however, the main diagnostic tools are: (1) clinical questionnaire to confirm clinical suspicions as initial screening, followed by (2) the instrumental measuring of muscle strength and quantity, and finally (3) the detection of muscle performance.

The prevalence of sarcopenia worldwide ranges from $10 \%$ to $40 \%$, based on the different characteristics of the population and the different criteria to assess it [12].

Different risk factors are involved in the age-related changes characterizing sarcopenia. These include genetic factors, gender, ethnical background, socioeconomic status, as well as modifiable factors such as low physical activity, poor diet [13-15], and sleep disturbance $[16,17]$, while the effects of alcohol consumption and cigarette smoking are not clear [18-20]. Comorbidities and pharmacological intervention might further contribute to sarcopenia in the elderly [14,15].

The mechanisms underlying the age-related changes involved in sarcopenia are not completely understood and are related to several and interacting processes: decline in the synthesis of muscle proteins [21], post-prandial resistance to synthesize protein in response to various nutritional factors [22], alteration in hormone balance (testosterone, dehydroepiandrosterone, vitamin $\mathrm{D}$, growth hormone, insulin-like growth factor 1 and cortisol) [23], intracellular lipid accumulation in the muscle [24], dysregulation of proteasomal degradation pathways [25], increase in oxidative stress and mitochondrial dysfunction [26], imbalance in proinflammatory cytokines [27], reduction in the number of satellite cells in the muscle [28], low motor unit remodeling [29].

Type 2 diabetes mellitus (T2DM) is one of the most common metabolic disease and represents an important health condition for the aging population, affecting one quarter of people over the age of 65 years; this proportion is projected to further increase in the next decades [30]. Individuals with T2DM are at a higher risk of developing sarcopenia [31-33].

However, it is possible that by improving the metabolic derangement in these patients by an appropriate treatment, the risk of sarcopenia may be reduced.

A life-course approach of behavior modification represents a key approach for the prevention and treatment of sarcopenia [15]. It is important to underline that, although the loss of muscle mass appears to be an inevitable part of the aging process, there is variation in the rates of decline across the population [34], indicating that modifiable behavioral factors could influence the development of sarcopenia. For instance, systematic reviews have shown that achieving the recommended levels of physical activity, in particular resistance-based training, is an effective protective strategy against sarcopenia and has a positive impact on muscle mass/strength and physical capacities in elderly [35-40]. Resistance-based training is similarly effective for improving muscle strength, size, and quality also in elderly with T2DM [41]. The role of a nutritional intervention for the prevention and treatment of sarcopenia is much less clear, although some evidence shows the benefit of healthier dietary patterns such as adequate intake of protein, vitamin $D$, antioxidants, and long-chain polyunsaturated fatty acids [42-45]. 
Beyond lifestyle changes, it should be considered that several glucose-lowering drugs are available for the treatment of T2DM, and they exert hypoglycemic activity throughout various mechanisms that may impact differently on the pathophysiological derangements leading to sarcopenia. In this respect, the scenery of pharmacological management of patients with T2DM has grown widely complex in the last years.

Guidelines suggest the need to account for heterogeneous characteristics of patients, putting the patients at the center of care, individualizing treatment targets and goals [46-49].

Currently, the most prescribed glucose-lowering drugs are metformin, thiazolidinediones (TZDs), sulfonylureas, dipeptidyl peptidase-4 inhibitors (DPP-4i), glucagon-like peptide-1 receptor agonists (GLP-1 RAs), sodium-glucose transport protein 2 inhibitors (SGLT2i), and insulin [50].

Against this background, the aim of this narrative review is to provide an update on the effects of glucose-lowering drugs on sarcopenia in individuals with T2DM, focusing on the parameters used to define sarcopenia: muscle strength (evaluated by handgrip strength), muscle quantity/quality (evaluated by appendicular lean mass or skeletal muscle mass or their indexes), and physical performance (evaluated by gait speed or short physical performance battery). Furthermore, we also describe the plausible mechanisms by which glucose-lowering drugs may impact on sarcopenia.

\section{Materials and Methods}

\subsection{Search Procedures}

Literature probing for this narrative review [51] was conducted by searching PubMed database for articles published during the last 20 years (2001-2021), considering that the majority of glucose-lowering drugs has been approved in the last twenty years; however, we also considered, if available, the most relevant studies before this period. The search dated from October 2020 to May 2021.

The medical subject heading (MeSH) terms "sarcopenia" OR "skeletal muscle mass" OR "muscle strength" OR "handgrip strength" OR "appendicular skeletal muscle mass" OR "muscle mass" OR "gait speed" AND "glucose-lowering drugs" OR "antidiabetic drugs" OR "metformin" OR "biguanides" OR "thiazolidinediones" OR "glitazones" OR "sulfonylureas" OR "DPP-4 inhibitors" OR "gliptins" OR "incretins" OR "GLP-1 receptor agonists" OR "SGLT2 inhibitors" OR "gliflozins" OR "insulin therapy" AND “diabetes" were utilized.

The search was limited to humans, clinical trials, and the English language.

An initial exploratory electronic database search was conducted by the two reviewers (E.M. and A.I.) to define the final search terms. Then, both reviewers independently conducted the main research. The herewith identified studies were screened for eligibility using titles and abstracts. The remaining full texts were assessed to ascertain whether they were fulfilling the inclusion and not fulfilling the exclusion criteria.

For the aim of our narrative review - the impact of glucose-lowering drugs on sarcopenia in T2DM - we focused particularly on clinical trials performed in individuals with T2DM, excluding retrospective and cross-sectional studies, meta-analyses, and systematic reviews on epidemiological studies.

Studies that did not meet the selection criteria, duplicate publications, non-original articles, consensus papers, letters to the editor, editorials, and studies in languages other than English were excluded.

Initially, 978 articles of potential intertest were found, and after screening of title and abstracts, and the assessment of the remaining full texts fulfilling the inclusion criteria, 36 papers were used for the aim of this narrative review.

\subsection{Sarcopenia Evaluation}

Different outcomes related to sarcopenia have been evaluated in the various trials. In particular, the most important parameters are muscle strength, muscle quantity / quality, and physical performance. The skeletal muscle strength is usually evaluated by a calibrated 
handheld dynamometer under well-defined test conditions with interpretive data from appropriate reference populations [5]; the chair stand test is a simple mode of evaluating strength and endurance when a disability comprising the handgrip evaluation is present [5] The muscle quantity /mass has been reported as total body Skeletal Muscle Mass (SMM), as Appendicular Skeletal Muscle Mass (ASM) or as muscle cross-sectional area of specific muscle groups or body locations. Because SMM/ASM strictly correlate with body size, they can be adjusted for height or for body mass index (BMI) - namely using height squared, weight or body mass index-resulting in skeletal muscle mass indexes (SMI). The major SMI used are ASM/height ${ }^{2}$ and SMM $/$ height $^{2}$.

Muscle quantity/mass has been evaluated by different techniques such as: Magnetic Resonance Imaging (MRI), Computed Tomography (CT), Dual-energy X-ray absorptiometry (DXA) [52,53]. Finally, bioelectrical impedance analysis (BIA) has been explored for estimation of total SMM or ASM indirectly by estimating muscle mass based on whole-body electrical conductivity [54].

Muscle performance has been measured by different methods such as gait speed, the Short Physical Performance Battery (SPPB), the Timed-Up and Go test (TUG), and the $400 \mathrm{~m}$ walk test. The gait speed test that is usually performed is called the $4 \mathrm{~m}$ usual walking speed test and requires the participant to move $4 / 6 \mathrm{~m}$ at a usual walking speed [55]. The SPPB is a composite test that includes assessment of gait speed, a balance test, and a chair stand [56]. For the TUG test, individuals are asked to rise from a standard chair, walk to a marker $3 \mathrm{~m}$ away, turn around, walk back, and sit down again [57]. The $400 \mathrm{~m}$ walk test assesses walking ability and endurance. For this test, participants are asked to complete 20 laps of $20 \mathrm{~m}[5]$.

\section{Effects of Glucose-Lowering Drugs on the Parameters of Sarcopenia}

\subsection{Metformin}

Evidence from epidemiological studies indicates that men with T2DM using insulin sensitizers, such as metformin and TZDs, lost significantly less SMM ( -1.1 vs. $-2.9 \%)$ or ASM ( -1.8 vs. $4.4 \%)$ than those treated without insulin sensitizers [58]. Similarly, in a cohort of 2864 women with T2DM, patients taking insulin sensitizers had less decline in usual walk speed than those not taking insulin sensitizers $(-1.07 \mathrm{vs} .-0.10 \mathrm{~m} / \mathrm{s})$, without significant differences in grip strength [59]. However, patients with T2DM and sarcopenia were significantly less likely to receive biguanides [60-63].

Although evidence from epidemiological studies show that metformin might have beneficial effect on parameters of sarcopenia, data from clinical trial are less consistent. Aghili et al. reported that in patients newly diagnosed with T2DM and placed on metformin (1000 mg/twice daily) for 24 weeks, men showed a greater significant increase in SMI $(+2.6 \%)$ than women; interestingly, in women, a reduction in the ASM $(-4 \%)$ was observed [64] (Table 1). In a prospective open-label observational study, overweight patients with T2DM and chronic obstructive pulmonary disease, treated with metformin ( $850 \mathrm{mg} /$ twice daily) for 24 weeks, showed a significant reduction in handgrip strength $(-3.2 \%)[65]$.

In contrast, in patients with T2DM treated with the DPP-4i sitagliptin randomized to receive the SGLT2i ipragliflozin (50 mg/daily) or metformin ( $1000 \mathrm{mg} /$ twice daily) for 24 weeks, there were no significant differences between the ipragliflozin and metformin groups regarding changes in abdominal muscle area ( $-2.9 \%$ vs. $-1.9 \%$, respectively) and handgrip strength $(+0.9 \%$ vs. $+8.8 \%$, respectively). However, analysis performed in the elderly population revealed that handgrip strength was significantly higher than that in the non-elderly following metformin treatment $(+8.8 \%$ vs. $+0.3 \%$, respectively) [66]. 
Table 1. Clinical trials on the effects of glucose-lowering drugs on the parameters of sarcopenia in patients with type 2 diabetes mellitus.

\begin{tabular}{|c|c|c|c|c|c|c|}
\hline Reference & Study Population & Study Design & Intervention & Duration & $\begin{array}{l}\text { Parameters of } \\
\text { Sarcopenia }\end{array}$ & Observed Effects \\
\hline \multicolumn{7}{|l|}{ Metformin } \\
\hline [64] & $\begin{array}{l}\text { Participants: } 21 \mathrm{M}, 30 \mathrm{~W} \\
\text { Age: } 53 \pm 10 \text { years } \\
\text { BMI: } 28.9 \pm 3.8 \mathrm{~kg} / \mathrm{m}^{2} \\
\text { HbA1c: } 8.2 \pm 2.0 \%\end{array}$ & $\begin{array}{l}\text { prospective, } \\
\text { uncontrolled }\end{array}$ & $\begin{array}{c}\text { Metformin } \\
\text { (2000 mg/daily) }\end{array}$ & 6 months & $\begin{array}{c}\text { SMI } \\
\text { secondary outcome }\end{array}$ & $\downarrow 0.31 \mathrm{~kg} / \mathrm{m}^{2} *$ \\
\hline [65] & $\begin{array}{l}\text { Participants: } 11 \mathrm{M}, 6 \mathrm{~W} \\
\text { Age: } 61 \pm 16 \text { years } \\
\text { BMI: } 29.1 \pm 14.9 \mathrm{~kg} / \mathrm{m}^{2} \\
\text { HbA1c: } 6.0 \pm 1.1 \%\end{array}$ & $\begin{array}{l}\text { prospective, } \\
\text { uncontrolled }\end{array}$ & Metformin (1700 mg/daily) & 6 months & $\begin{array}{c}\text { Handgrip } \\
\text { strength } \\
\text { secondary outcome }\end{array}$ & $\downarrow 1.0 \mathrm{~kg}$ \\
\hline [66] & $\begin{array}{c}\text { Participants: } 14 \mathrm{M}, 15 \mathrm{~W} \\
\text { Age: } 69 \pm 3 \text { years } \\
\text { BMI: } 26.9 \pm 3.9 \mathrm{~kg} / \mathrm{m}^{2} \\
\text { HbA1c: } 8.0 \pm 0.8 \%\end{array}$ & $\begin{array}{l}\text { prospective, } \\
\text { multicenter, } \\
\text { randomized, } \\
\text { controlled }\end{array}$ & $\begin{array}{l}\text { Metformin (500 mg/daily) } \\
\text { vs. } \\
\text { Ipragliflozin ( } 50 \mathrm{mg} / \text { daily) }\end{array}$ & 6 months & $\begin{array}{c}\text { Handgrip } \\
\text { strength } \\
\text { secondary outcome }\end{array}$ & $\uparrow 0.25 \mathrm{~kg} \S$ \\
\hline \multicolumn{7}{|c|}{ Dipeptidyl Peptidase-4 Inhibitors } \\
\hline [67] & $\begin{array}{l}\text { Participants: } 11 \mathrm{M}, 9 \mathrm{~W} \\
\text { Age: } 52 \pm 8 \text { years } \\
\text { BMI: } 29.7 \pm 3.2 \mathrm{~kg} / \mathrm{m}^{2} \\
\text { HbA1c: } 8.2 \pm 1.3 \%\end{array}$ & $\begin{array}{l}\text { prospective, } \\
\text { controlled }\end{array}$ & $\begin{array}{l}\text { Sitagliptin (50 mg/daily) } \\
\text { vs. } \\
\text { Glimepiride ( } 1 \mathrm{mg} / \text { daily) }\end{array}$ & 6 months & $\begin{array}{c}\mathrm{SMM}^{+} \\
\text {secondary outcome }\end{array}$ & $\uparrow 1.24 \mathrm{~kg}$ \\
\hline \multicolumn{7}{|c|}{ Glucagon-Like Peptide-1 Receptor Agonists } \\
\hline [68] & $\begin{array}{l}\text { Participants: } 16 \mathrm{M}, 5 \mathrm{~W} \\
\text { Age: } 68 \pm 11 \text { years } \\
\text { BMI: } 23.1 \pm 5.5 \mathrm{~kg} / \mathrm{m}^{2} \\
\text { HbA1c: n.a. }\end{array}$ & $\begin{array}{l}\text { prospective, } \\
\text { controlled }\end{array}$ & $\begin{array}{c}\text { Dulaglutide (0.75 mg/weekly) } \\
\text { vs. } \\
\text { Teneligliptin ( } 20 \mathrm{mg} / \text { daily })\end{array}$ & 6 months & $\begin{array}{c}\text { SMI } \\
\text { primary outcome }\end{array}$ & $\downarrow 0.10 \mathrm{~kg} / \mathrm{m}^{2}$ \\
\hline [69] & $\begin{array}{l}\text { Participants: } 6 \mathrm{M}, 3 \mathrm{~W} \\
\text { Age: } 68 \pm 4 \text { years } \\
\text { BMI: } 32.3 \pm 4.9 \mathrm{~kg} / \mathrm{m}^{2} \\
\text { HbA1c: } 7.9 \pm 1.8 \%\end{array}$ & $\begin{array}{l}\text { prospective, } \\
\text { uncontrolled }\end{array}$ & $\begin{array}{l}\text { Liraglutide } \\
\text { (3 mg/daily) }\end{array}$ & 6 months & $\begin{array}{c}\text { SMI } \\
\text { primary outcome }\end{array}$ & $\uparrow 0.03 \mathrm{~kg} / \mathrm{m}^{2}$ \\
\hline [70] & $\begin{array}{l}\text { Participants: } 16 \mathrm{M}, 12 \mathrm{~W} \\
\text { Age: } 58 \pm 10 \text { years } \\
\text { BMI: } 34.1 \pm 5.4 \mathrm{~kg} / \mathrm{m}^{2} \\
\text { HbA1c: } 8.3 \pm 1.5 \%\end{array}$ & $\begin{array}{l}\text { prospective, } \\
\text { uncontrolled }\end{array}$ & $\begin{array}{l}\text { Liraglutide } \\
\text { (3 mg/daily) }\end{array}$ & 6 months & $\begin{array}{c}\text { SMM } \\
\text { primary outcome }\end{array}$ & $=$ \\
\hline [71] & $\begin{array}{l}\text { Participants: } 32 \mathrm{M} / \mathrm{W} \\
\text { Age: } 49 \pm 11 \text { years } \\
\text { BMI: } 32.9 \pm 4.7 \mathrm{~kg} / \mathrm{m}^{2} \\
\text { HbA1c: } 8.7 \pm 1.7 \%\end{array}$ & $\begin{array}{l}\text { prospective, } \\
\text { uncontrolled }\end{array}$ & $\begin{array}{c}\text { Exenatide } \\
(20 \mu \mathrm{g} / \text { twice daily })\end{array}$ & 3 months & $\begin{array}{c}\text { SMM } \\
\text { secondary outcome }\end{array}$ & $=$ \\
\hline \multicolumn{7}{|c|}{ Sodium-Glucose Transport Protein 2 Inhibitors } \\
\hline [72] & $\begin{array}{c}\text { Participants: } 81 \mathrm{M}, 38 \mathrm{~W} \\
\text { Age: } 54 \pm 11 \text { years } \\
\text { BMI: } 28.6 \pm 5.7 \mathrm{~kg} / \mathrm{m}^{2} \\
\text { HbA1c: } 7.5 \pm 1.4 \%\end{array}$ & $\begin{array}{l}\text { multicenter, } \\
\text { controlled, } \\
\text { randomized, }\end{array}$ & $\begin{array}{c}\text { Ipragliflozin (50 mg/daily) } \\
\text { vs. } \\
\text { Sitagliptin (50 mg/daily) }\end{array}$ & 3 months & $\begin{array}{c}\text { SMI } \\
\text { secondary outcome }\end{array}$ & $\downarrow 0.10 \mathrm{~kg} / \mathrm{m}^{2}$ \\
\hline [73] & $\begin{array}{c}\text { Participants: } 92 \mathrm{M}, 20 \mathrm{~W} \\
\text { Age: } 63 \pm 10 \text { years } \\
\text { BMI: } 24.5 \pm 4.3 \mathrm{~kg} / \mathrm{m}^{2} \\
\text { HbA1c: } 7.0 \pm 1.3 \%\end{array}$ & $\begin{array}{l}\text { prospective, } \\
\text { uncontrolled }\end{array}$ & $\begin{array}{c}\text { Ipragliflozin } 50 \mathrm{mg}, \\
\text { luseogliflozin } 2.5 \mathrm{mg} \text {, or } \\
\text { dapagliflozin } 5 / 10 \mathrm{mg} \text { daily }\end{array}$ & 2.5 months & $\begin{array}{c}\text { Handgrip } \\
\text { strength } \\
\text { primary outcome }\end{array}$ & $\uparrow \sim 1 \mathrm{~kg}$ \\
\hline [74] & $\begin{array}{c}\text { Participants: } 34 \mathrm{M}, 23 \mathrm{~W} \\
\text { Age: } 57 \pm 12 \text { years } \\
\text { BMI: } 27.9 \pm 4.1 \mathrm{~kg} / \mathrm{m}^{2} \\
\text { HbA1c: } 7.8 \pm 3.1 \%\end{array}$ & $\begin{array}{l}\text { randomized, } \\
\text { controlled trial }\end{array}$ & $\begin{array}{c}\text { Dapagliflozin (5 mg/daily) } \\
\text { vs. } \\
\text { standard treatment }\end{array}$ & 6 months & $\begin{array}{c}\text { SMM } \\
\text { secondary outcome }\end{array}$ & $\downarrow 0.9 \mathrm{~kg}$ \\
\hline$[75]$ & $\begin{array}{c}\text { Participants: } 36 \mathrm{M}, 24 \mathrm{~W} \\
\text { Age: } 56 \pm 8 \text { years } \\
\text { BMI: } 27.1 \pm 2.9 \mathrm{~kg} / \mathrm{m}^{2} \\
\text { HbA1c: } 7.7 \pm 0.5 \%\end{array}$ & $\begin{array}{l}\text { prospective, } \\
\text { controlled }\end{array}$ & $\begin{array}{l}\text { Dapagliflozin ( } 5 \mathrm{mg} / \text { daily) } \\
\text { vs. } \\
\text { oral glucose-lowering drugs }\end{array}$ & 6 months & $\begin{array}{c}\text { SMI } \\
\text { primary outcome }\end{array}$ & $=$ \\
\hline [76] & $\begin{array}{c}\text { Participants: } 25 \mathrm{M}, 29 \mathrm{~W} \\
\text { Age: } 60 \pm 13 \text { years } \\
\text { BMI: } 31.0 \pm 6.9 \mathrm{~kg} / \mathrm{m}^{2} \\
\text { HbA1c: } 7.5 \pm 0.9 \%\end{array}$ & $\begin{array}{c}\text { randomized, } \\
\text { controlled trial }\end{array}$ & $\begin{array}{c}\text { Dapagliflozin ( } 5 \mathrm{mg} / \text { daily) } \\
\text { vs. } \\
\text { oral glucose-lowering drugs }\end{array}$ & 6 months & $\begin{array}{c}\text { SMM } \\
\text { secondary }\end{array}$ & $=$ \\
\hline$[77]$ & $\begin{array}{c}\text { Participants: } 9 \mathrm{M}, 7 \mathrm{~W} \\
\text { Age: } 53 \pm 16 \text { years } \\
\text { BMI: } 31.0 \pm 2.2 \mathrm{~kg} / \mathrm{m}^{2} \\
\text { HbA1c: } 7.4 \pm 0.5 \%\end{array}$ & $\begin{array}{l}\text { prospective, } \\
\text { uncontrolled }\end{array}$ & $\begin{array}{l}\text { Dapagliflozin } \\
\text { (5 mg/daily) }\end{array}$ & 6 months & $\begin{array}{c}\text { SMI } \\
\text { secondary outcome }\end{array}$ & $=$ \\
\hline
\end{tabular}


Table 1. Cont.

\begin{tabular}{|c|c|c|c|c|c|c|}
\hline Reference & Study Population & Study Design & Intervention & Duration & $\begin{array}{c}\text { Parameters of } \\
\text { Sarcopenia }\end{array}$ & Observed Effects \\
\hline [78] & $\begin{array}{c}\text { Participants: } 27 \mathrm{M}, 10 \mathrm{~W} \\
\text { Age: } 54 \pm 8 \text { years } \\
\text { BMI: } 28.0 \pm 3.4 \mathrm{~kg} / \mathrm{m}^{2} \\
\text { HbA1c: } 7.7 \pm 0.7 \%\end{array}$ & $\begin{array}{l}\text { prospective, } \\
\text { uncontrolled }\end{array}$ & $\begin{array}{l}\text { Luseogliflozin } \\
\text { (5 mg/daily) }\end{array}$ & 12 months & $\begin{array}{c}\text { SMI } \\
\text { primary outcome }\end{array}$ & $\downarrow 0.15 \mathrm{~kg} / \mathrm{m}^{2}$ \\
\hline [79] & $\begin{array}{l}\text { Participants: } 12 \mathrm{M}, 5 \mathrm{~W} \\
\text { Age: } 52 \pm 12 \text { years } \\
\text { BMI: } 28.2 \pm 2.7 \mathrm{~kg} / \mathrm{m}^{2} \\
\text { HbA1c: } 7.5 \pm 0.7 \%\end{array}$ & $\begin{array}{l}\text { prospective, } \\
\text { uncontrolled }\end{array}$ & $\begin{array}{l}\text { Luseogliflozin } \\
\text { (5 mg/daily) }\end{array}$ & 3 months & $\begin{array}{c}\text { SMI } \\
\text { secondary outcome }\end{array}$ & $\downarrow 0.23 \mathrm{~kg} / \mathrm{m}^{2}$ \\
\hline$[80]$ & $\begin{array}{l}\text { Participants: } 11 \mathrm{M}, 9 \mathrm{~W} \\
\text { Age: } 51 \pm 9 \text { years } \\
\text { BMI: } 31.5 \pm 8.0 \mathrm{~kg} / \mathrm{m}^{2} \\
\text { HbA1c: } 8.7 \pm 1.4 \%\end{array}$ & $\begin{array}{l}\text { prospective, } \\
\text { uncontrolled }\end{array}$ & $\begin{array}{l}\text { Canagliflozin } \\
\text { (100 mg/daily) }\end{array}$ & 12 months & $\begin{array}{c}\text { SMM } \\
\text { secondary outcome }\end{array}$ & $=$ \\
\hline [81] & $\begin{array}{c}\text { Participants: } 27 \mathrm{M}, 21 \mathrm{~W} \\
\text { Age: } 60 \pm 11 \text { years } \\
\text { BMI: } 27.8 \pm 4.2 \mathrm{~kg} / \mathrm{m}^{2} \\
\text { HbA1c: } 8.2 \pm 0.8 \%\end{array}$ & $\begin{array}{l}\text { randomized, } \\
\text { controlled trial }\end{array}$ & $\begin{array}{c}\text { Ipragliflozin ( } 50 \mathrm{mg} / \text { daily) } \\
\text { vs. } \\
\text { control }\end{array}$ & 6 months & $\begin{array}{c}\text { SMM } \\
\text { secondary outcome }\end{array}$ & $=$ \\
\hline [82] & $\begin{array}{l}\text { Participants: } 8 \mathrm{M}, 16 \mathrm{~W} \\
\text { Age: } 52 \pm 12 \text { years } \\
\text { BMI: } 28.9 \pm 5.4 \mathrm{~kg} / \mathrm{m}^{2} \\
\text { HbA1c: } 7.7 \pm 0.7 \%\end{array}$ & $\begin{array}{l}\text { prospective, } \\
\text { uncontrolled }\end{array}$ & $\begin{array}{l}\text { Ipragliflozin } \\
\text { (50 mg/daily) }\end{array}$ & 4 months & $\begin{array}{c}\text { SMI } \\
\text { primary outcome }\end{array}$ & $\downarrow 0.02 \mathrm{~kg} / \mathrm{m}^{2}$ \\
\hline [83] & $\begin{array}{c}\text { Participants: } 234 \mathrm{M}, 217 \\
\text { W } \\
\text { Age: } 55 \pm 12 \text { years } \\
\text { BMI: } 29.4 \pm 5.3 \mathrm{~kg} / \mathrm{m}^{2} \\
\text { HbA1c: } 8.0 \pm 1.4 \%\end{array}$ & $\begin{array}{l}\text { multicenter, } \\
\text { prospective }\end{array}$ & $\begin{array}{l}\text { Ipragliflozin } \\
\text { (50 mg/daily) }\end{array}$ & 24 months & $\begin{array}{c}\text { SMM } \\
\text { secondary outcome }\end{array}$ & $\downarrow 0.87 \mathrm{~kg}$ \\
\hline [84] & $\begin{array}{l}\text { Participants: } 16 \mathrm{M}, 4 \mathrm{~W} \\
\text { Age: } 52 \pm 10 \text { years } \\
\text { BMI: } 29.0 \pm 5.0 \mathrm{~kg} / \mathrm{m}^{2} \\
\text { HbA1c: } 8.5 \pm 1.0 \%\end{array}$ & $\begin{array}{l}\text { prospective, } \\
\text { uncontrolled }\end{array}$ & $\begin{array}{l}\text { Ipragliflozin } \\
\text { (50 mg/daily) }\end{array}$ & 3 months & $\begin{array}{c}\text { SMM } \\
\text { secondary outcome }\end{array}$ & $\downarrow 0.57 \mathrm{~kg}$ \\
\hline [85] & $\begin{array}{l}\text { Participants: } 2 \mathrm{M}, 10 \mathrm{~W} \\
\text { Age: } 62 \pm 15 \text { years } \\
\text { BMI: } 27.7 \pm 5.0 \mathrm{~kg} / \mathrm{m}^{2} \\
\text { HbA1c: } 7.6 \pm 1.1 \%\end{array}$ & $\begin{array}{l}\text { prospective, } \\
\text { uncontrolled }\end{array}$ & $\begin{array}{l}\text { Ipragliflozin } \\
\text { (50 mg/daily) }\end{array}$ & 6 months & $\begin{array}{c}\text { SMM } \\
\text { secondary outcome }\end{array}$ & $=$ \\
\hline [86] & $\begin{array}{c}\text { Participants: } 9 \text { M, } 5 \mathrm{~W} \\
\text { Age: } 58 \pm 10 \text { years } \\
\text { BMI: } 28.9 \pm 4.6 \mathrm{~kg} / \mathrm{m}^{2} \\
\text { HbA1c: } 8.2 \pm 0.7 \%\end{array}$ & $\begin{array}{l}\text { prospective, } \\
\text { uncontrolled }\end{array}$ & $\begin{array}{l}\text { Tofogliflozin } \\
\text { (20 mg/daily) }\end{array}$ & 3 months & $\begin{array}{c}\text { SMM } \\
\text { secondary outcome }\end{array}$ & $\downarrow 1.37 \mathrm{~kg}$ \\
\hline \multicolumn{7}{|l|}{ Insulin } \\
\hline [87] & $\begin{array}{c}\text { Participants: } 60 \mathrm{M}, 58 \mathrm{~W} \\
\text { Age: } 76 \pm 6 \text { years } \\
\text { BMI: } 30.5 \pm 4.2 \mathrm{~kg} / \mathrm{m}^{2} \\
\text { HbA1c: } 6.5 \pm 0.6 \%\end{array}$ & $\begin{array}{l}\text { prospective, } \\
\text { controlled }\end{array}$ & $\begin{array}{c}\text { Insulin } \\
\text { vs. } \\
\text { oral glucose-lowering drugs }\end{array}$ & 36 months & $\begin{array}{c}\text { SMI } \\
\text { secondary outcome }\end{array}$ & $\uparrow 0.15 \mathrm{~kg} / \mathrm{m}^{2}$ \\
\hline
\end{tabular}

M, men; W, women; BMI, Body mass index; HbA1c, glycated hemoglobin A1c; SMI, skeletal muscle index; SMM, skeletal muscle mass; n.a., not available. $=$, no significant changes; ${ }^{*}$ in women; ${ }^{\S}$ in the elderly; ${ }^{\dagger}$ fat and bone-free mass. SMI and SMM were evaluated by dual-energy X-ray absorptiometry or bioelectrical impedance analysis. SMI was calculated as appendicular skeletal muscle mass $/$ height $^{2}$ or skeletal muscle mass / height ${ }^{2}$.

In support of a possible beneficial influence of metformin on sarcopenia, there are also data from a clinical trial performed in elderly individuals without T2DM showing a significant improvement in mean walking time (by $0.39 \mathrm{~s}$ ) with this drug; this value corresponds to an improvement of the mean gait speed of $0.13 \mathrm{~m} / \mathrm{s}$ [88]. Importantly, it should be considered that all the reported trials suffer of important methodological limitations of, such as a small sample size, a relatively short trial duration and an open label design.

\subsection{Thiazolidinediones}

As reported above, epidemiological studies show that TZDs in patient with T2DM were associated with a significantly lower reduction in muscle mass and usual walk speed $[58,59]$. In contrast, data from clinical trials are scarce and conflicting. Furthermore, the few trials available were performed in individuals without T2DM.

Yokota et al. investigated the effects of the TZD pioglitazone ( $15 \mathrm{mg} /$ daily) in individuals at risk for T2DM. After 16 weeks of treatment there was no significant change in the cross-sectional area of the calf muscle $\left(57.9\right.$ vs. $\left.58.2 \mathrm{~cm}^{2}\right)$. Notably, pioglitazone reduced 
the intra-myocellular lipid content, improved skeletal muscle fatty acid metabolism, and decreased the muscle phosphocreatine loss during exercise, indicating improved skeletal muscle high-energy phosphate metabolism [89]. Bastien et al. evaluated the effect of rosiglitazone vs. placebo on aerobic exercise capacity and body composition/distribution in men with T2DM and stable coronary artery disease. After one year, patients randomized to rosiglitazone showed no significant changes in lean mass and total mid-thigh SMM $\left(-1\right.$ vs. $\left.-5 \mathrm{~cm}^{2}\right)$ [90].

In contrast, a trial performed in individuals without T2DM has shown that men who were given pioglitazone lost more thigh muscle volume, compared to men who were not given pioglitazone; however, muscle resistance training was effective in counteracting muscle loss [91]. Furthermore, pioglitazone was able to potentiate the effect of resistance training on muscle strength in women but not in men [92].

Further well-designed trials are needed to elucidate the effects of TZDs on sarcopenia in patients with T2DM.

\subsection{Sulfonylureas}

Data from the Food and Drug Administration-Adverse Effects Reporting System database show that during an 8-month observational period, muscle atrophy was found in $0.27 \%$ of the glibenclamide/glyburide reports in humans and in $0.02 \%$ of the other non-sulfonylureas drugs [93].

In a cross-sectional study, Rizzo et al. observed that sarcopenic parameters (SMM, SMI, muscle strength, and gait speed) were significantly worse in patients with T2MD taking sulfonylureas compared with DPP-4i [94], while in a clinical trial no changes in SMM were reported in patients with T2DM assigned to sulfonylureas [67].

\subsection{Dipeptidyl Peptidase-4 Inhibitors}

Epidemiological evidence shows that elderly diabetic patients treated with DPP-4i have better parameters of sarcopenia compared with those treated with other glucoselowering drugs [94].

Again, Ishii et al. reported that SMM significantly increased in overweight/obese patients with T2DM assigned to the DPP-4i sitagliptin (+2.6\%) compared with sulfonylurea $(-0.7 \%)$ after 24 weeks of treatment [67]. In a randomized, multicenter, controlled study, patients with T2DM were assigned to receive the DPP-4i sitagliptin (50 mg/daily) or the SGLT2i ipragliflozin. After 12 weeks, a significant decrease in SMI $\left(-0.10 \mathrm{~kg} / \mathrm{m}^{2}\right)$ was observed only in the ipragliflozin group, while no changes in the sitagliptin group were reported [72]. Similarly, in overweight/obese patients with T2DM, no changes in SMM and SMI were reported following 24 weeks of the DPP-4i teneligliptin ( $20 \mathrm{mg} /$ daily) compared with the GLP-1 RAs dulaglutide; during the latter drug, a reduction in both the evaluated markers of sarcopenia was observed [68] (Table 1). Although scarce, these few data suggest that DPP-4i, beyond their proven efficacy and safety in terms of glucose control in elderly patients with T2DM [46-49], might be a good choice with respect to the risk of sarcopenia due to their neutral impact.

\subsection{Glucagon-Like Peptide-1 Receptor Agonists}

Six months of the GLP-1 RAs dulaglutide treatment ( $0.75 \mathrm{mg} /$ weekly) compared with the DPP-4i teneligliptin (20 mg/daily) significantly reduced SMI $(-1.2 \%)$ in patients with T2DM treated with insulin and on hemodialysis. Furthermore, in the dulaglutide group SMM was significantly decreased (-3.8\%) [68] (Table 1). However, it is important to underline that in this study the participants were more likely to develop sarcopenia, considering the age-higher than in other studies-and the presence of complications related to advanced renal failure in all patients [68].

Conversely, Perna et al. assessed the effect of the GLP-1 RAs liraglutide ( $3 \mathrm{mg} /$ daily) on SMM changes in overweight and obese elderly patients with T2DM. After 24 weeks, a worsening in the parameters of sarcopenia was not observed in any patients under 
treatment; importantly, five patients even showed an improvement in SMI [69]. Another trial shows that liraglutide over 24 weeks induced a non-significant reduction in SMM $(-0.6 \%)$ [70]. Similarly, Hong et al. did not report significant changes in SMM $(+4.3 \%)$ after 12 weeks of treatment with the GLP-1 RAs exenatide (20 $\mathrm{g}$ /twice daily) [71] (Table 1).

\subsection{Sodium-Glucose Transport Protein 2 Inhibitors}

In recent years, many trials focusing on the effects of SGLT2i on the parameters of sarcopenia have been performed. A study conducted in Japanese patients with T2DM showed that the treatment with SGLT2i (ipragliflozin $50 \mathrm{mg}$, luseogliflozin $2.5 \mathrm{mg}$, or dapagliflozin 5/10 mg daily) after 10 weeks increased grip strength [73]. In patients with T2DM and non-alcoholic fatty liver disease (NAFLD), dapagliflozin ( $5 \mathrm{mg} /$ daily) significantly decrease SMM (-2.1\%) compared with the standard treatment after 24 weeks [74]. In contrast, Sugiyama et al. showed that SMI did not significantly decrease in overweight patients with T2DM after treatment with dapagliflozin ( $5 \mathrm{mg}$ /daily) compared with non SGLT2i (-0.8 vs. $-8.0 \%$ ); furthermore, both treatments produced a non-significant reduction in SMM (-0.7\%) [75]. Similarly, Yamakage et al. showed no differences in SMM in obese patients with T2DM after treatment with dapagliflozin ( $5 \mathrm{mg} /$ daily) compared with non-SGLT2i (+0.4 vs. $-0.7 \%$ ) [76]. On the other hand, in patients with T2DM and non-alcoholic steatohepatitis, dapagliflozin ( $5 \mathrm{mg} /$ daily) promoted a significant increase in ASM (+2.2\%), without changes in SMM (+0.4\%) and SMI (+1.2\%) after 24 weeks [77].

Luseogliflozin (5 mg/day) induced a significant reduction in SMI at and after 36 weeks $(-1.9 \%)$ in obese patients with T2DM [78]. Similarly, overweight patients with T2DM treated with luseogliflozin (5 mg/day) showed a significant reduction in SMM $(-2.2 \%)$ and SMI (-2.9\%) after 12 weeks [79].

In a prospective single-arm study, patients with T2DM and NAFLD were treated with canagliflozin (100 mg/day). After 56 weeks, a not significant slight decrease in SMM $(-0.4 \%)$ was observed [80].

Overweight patients with T2DM receiving insulin treatment were randomly assigned to add-on ipragliflozin ( $50 \mathrm{~g}$ /day) or no additional treatment. After 24 weeks, the change in SMM was somewhat larger in ipragliflozin than in the control group, but the difference was not significant $(+0.1$ vs. $-1.2 \%$ ) [81]. In contrast, another trial with ipragliflozin (50 mg/once daily) reported a significant reduction in SMI $(-2.7 \%)$ by week 8 and this reduction remained at the end of the study [82].

In a multicenter prospective Japanese study, patients received ipragliflozin (50 mg/daily) as monotherapy or combined with other glucose-lowering drugs for up to 104 weeks shown a significant reduction in SMM $(-0.9 \mathrm{~kg})$ [83].

Similarly, a significant reduction in SMM $(-0.6 \mathrm{~kg})$ following ipragliflozin treatment (50 mg/daily) for 12 weeks was observed in a small trial [84]. In contrast, Miyake et al. find a not significant reduction in SMM $(-2.2 \%)$ after 24 weeks of treatment with ipragliflozin (50 mg/daily) in patients with T2DM and NAFLD [85].

Matsuba et al. investigated the impact of tofogliflozin $(20 \mathrm{mg} /$ daily $)$ in patients with T2DM showing a significant decrease in SMM $(-1.4 \mathrm{~kg})$ after 12 weeks of treatment [86].

Summarizing, clinical trials consistently show that reduction in SMI and SMM can occur during treatment with SGLT2i [72,74,78,79,82-84,86], and muscle mass loss may represent a major concern with the use of SGLT2i, especially in elderly and lean patients, (Table 1). However, in one trial an improvement in grip strength [73] and ASM [77] was reported, (Table 1).

Finally, in six trials no significant changes on SMI and SMM were reported $[75-77,80,81,85]$ (Table 1).

Further studies evaluating the effects of SGLT2i on sarcopenic parameters should be considered, particularly in normal weight elderly patients, in good metabolic control, also considering a larger sample size and various ethnic backgrounds. 


\subsection{Insulin}

Epidemiological evidence suggests that patients with T2DM and sarcopenia are more frequent insulin users [95]. A retrospective observational study reported that insulin treatment prevented the decline of SMI in the lower extremities [96].

In 118 participants with T2DM of the population-based KORA-Age study, during a follow-up of three years, the SMI decline was significantly more marked in patients treated with oral glucose-lowering drugs compared to insulin therapy, suggesting a positive effect of insulin treatment on muscle mass. In particular, women on insulin therapy displayed a significantly greater increase in time needed to complete the TUG than women treated with oral glucose-lowering drugs ( $2.6 \mathrm{vs}$. $0.7 \mathrm{~s}$, respectively), despite more favorable-albeit not statistically significant-changes in SMI over time compared to those treated with oral glucose-lowering drugs ( +0.1 vs. $-0.3 \mathrm{~kg} / \mathrm{m}^{2}$, respectively). In men, the change in SMI differed significantly between participants treated with insulin compared with those treated with oral glucose-lowering drugs ( $+0.2 \mathrm{vs} .-0.3 \mathrm{~kg} / \mathrm{m}^{2}$, respectively), whereas changes in TUG did not differ in men with or without insulin therapy. Changes in gait speed were not significantly differed in women or men with and without insulin therapy [87] (Table 1).

\section{Type 2 Diabetes Mellitus and Sarcopenia}

Type 2 diabetes mellitus (T2DM) represents an important health burden in the elderly population, affecting approximately $25 \%$ of people over the age of 65 years; this proportion is expected to further increase in the next decades [30]. Increasing attention has been paid to sarcopenia in individuals with T2DM for its heavy impact on the quality of life of elderly patients with T2DM [97], in whom frailty and sarcopenia-in addition to the traditional microvascular and macrovascular complications of diabetes-are emerging as a third category of complications leading to disability [98]. A higher prevalence of sarcopenia has been consistently reported in T2DM (ranging from 5 to $50 \%$ ) than in individuals without T2DM [31-33].

The risk factors related to sarcopenia in elderly people with T2DM are age, diabetes duration, gender, presence of comorbidity, microvascular complications [32,99], reduced hip circumference, lower BMI, low physical activities [100], and poor nutritional status [101,102].

Different mechanisms may explain the higher prevalence of sarcopenia in individuals with T2DM. The anabolic effects of insulin on the skeletal muscle are well known; their pathways involve phosphoinositide3-kinase, phosphoinositol triphosphate, protein kinase $\mathrm{B} / \mathrm{AKT}, \mathrm{TBC} 1$ domain family member 4 and 1 . In addition to the synthesis of protein, these pathways induce the translocation of glucose transporter type 4 (GLUT4) containing vesicles to the plasma membrane [103], and the dis-inhibition of glycogen synthesis by phosphorylation of glycogen synthase kinase 3, leading to an improvement in muscle metabolism. AKT also induces the activation of mTOR, which promotes protein synthesis, and inhibits fork head box protein $\mathrm{O}$ activity, thus reducing the expression of E3 ubiquitin ligases that mediate the atrophy of muscle cells [104]. All these pathways are progressively impaired by the insulin resistance associated with T2DM that may lead to a decrease in protein synthesis and an increased protein degradation, thus promoting loss in muscle mass and strength [105]. Again, insulin resistance decreases muscle mass and muscle contractility due to the increase in inflammatory cytokines, myostatin expression, together with the reduction in blood flow and skeletal muscle glucose uptake [106]. Interestingly, patients with a longer duration of T2DM are more likely to decrease muscle mass and strength predominantly in the lower extremities rather than in the upper extremities $[107,108]$, probably due to a reduction in numbers of the predominantly oxidative fiber type [109].

Chronic hyperglycemia in T2DM promotes per se an increase in advanced glycosylation end products (AGEs) in skeletal muscle that might affect muscle mass, grip strength, leg extension power, and walking speed [110]. AGEs may increase oxidative stress, inflammatory cytokines, and promote the formation of cross-links and breakdowns of muscular proteins in elderly individuals [111,112]. Importantly, when blood glucose levels are high, a large amount of glucose is channeled into the polyol pathway, resulting in enhanced forma- 
tion of sorbitol which is converted by sorbitol dehydrogenase to fructose. The metabolites derived from the polyol pathway reduce cellular antioxidant defense, promote the formation of AGE precursor (methylglyoxal) via auto-oxidation, and activate the protein kinase $\mathrm{C}$ pathway via de novo synthesis of diacylglycerol. These phenomena collectively promote oxidative stress and inflammation [113].

In T2DM an increase in low-grade inflammation and some inflammatory cytokines has been reported [114]. Available evidence shows that inflammatory cytokines, such as tumor necrosis factor- $\alpha$, interleukin- 6 , and $C$ reactive protein, may negatively affect muscle mass, strength and function by promoting muscle atrophy via blunting muscle anabolism and energy homeostasis, and promoting muscle protein degradation via the NF-kB pathways $[27,30,98]$. Oxidative stress is strictly related to low grade inflammation; increasing evidence suggests that oxidative stress plays a pivotal role in the pathophysiology of insulin resistance and T2DM $[115,116]$, as well as in age-related muscle changes and sarcopenia by affecting skeletal muscle size, fiber activation, excitation-contraction coupling, and cross-bridge cycling [117-119].

Finally, the presence of microvascular-retinopathy, nephropathy, and neuropathyand macrovascular - cardiovascular diseases-diabetic complications may further explain the higher prevalence of sarcopenia in T2DM. In particular, retinopathy and the associated visual impairment may impact on balance, involved in both locomotion and physical performance, causing mobility limitations that might affect physical activity [120], muscle strength and quality [121]. Nephropathy may contribute to sarcopenia, in particular promoting muscle loss, through metabolic acidosis, mitochondrial dysfunction, increased inflammation, protein loss, reduced vitamin D synthesis, defects in insulin/insulin-like growth factor 1 intracellular signaling, inflammation and catabolic responses [122]. Peripheral diabetic neuropathy is characterized by the accelerated loss of motor units resulting in muscle weakness, atrophy, and intramuscular fatty infiltration that favor loss of muscle strength, power, and endurance [123,124]. Macrovascular complications, such as peripheral vascular disease, may favor muscle ischemia, as well as lower muscle strength, mass, and performance [125].

\section{Glucose-Lowering Drugs and Mechanisms of Their Potential Impact on Sarcopenia}

Several glucose-lowering drugs for the treatment of T2DM have become available in the last years. All glucose-lowering drugs for T2DM can beneficially impact on some of the mechanisms possibly involved in sarcopenia; in fact, they improve blood glucose control and insulin sensitivity, inhibit AGEs formation, and improve inflammation and the oxidative stress. Moreover, glucose-lowering drugs such as TZDs, GLP-1 RAs and SGLT2i have been shown also to reduce the incidence and progression of microvascular and macrovascular complications [46-49]. On the other hand, some of them-metformin, GLP-1 RAs, and SGLT2i-have a potential detrimental effect on the risk of sarcopenia since they help to decrease body weight by reducing energy intake or increasing glucose excretion by glycosuria, negatively impacting on muscle mass. For contrasting reasons, sulfonylureas and insulin, which favor weight gain, can also increase the risk of sarcopenia, since this can aggravate insulin resistance and related mechanisms involved in the pathogenesis of sarcopenia. Furthermore, beyond their glucose-lowering effects, glucose-lowering drugs may affect per se the equilibrium between protein anabolism and catabolism through several mechanisms involved in skeletal muscle physiology, thus contributing to sarcopenia; however, data on this aspect are unclear or controversial, and human studies in most cases are lacking.

\subsection{Metformin}

Metformin is the most widely prescribed drug for the treatment of T2DM and it promotes a glucose-lowering effect by the activation of the AMP-activated protein kinase (AMPK) pathway that leads to an inhibition of hepatic gluconeogenesis. Furthermore, metformin acts on skeletal muscle by increasing insulin-stimulated glucose uptake, and on 
gastrointestinal tract promoting gut microbiome changes, intestinal glucose uptake, and secretion of gastrointestinal hormones [126]

The possible beneficial effects of metformin on parameters of sarcopenia observed in the few clinical trials performed so far could be related to different mechanisms (Figure 1). Metformin could act on muscle by activating AMPK and stimulating gene expression of peroxisome proliferator-activated receptor- $\gamma$ coactivator 1- $\alpha$ to upregulate the transcription of genes involved in fatty acid oxidation, thus reducing muscle lipid accumulation; furthermore, the activation of the AMPK pathway could stimulate angiogenesis, increase mitochondrial biogenesis, and switch muscle fiber types from glycolytic to more oxidative fatigue-resistant fibers [127-129]. Furthermore, the inhibition of NF- $\mathrm{kB}$ signaling by AMPK activation could suppress the inflammatory response, which contributes to depress muscle protein breakdown [130]. On the other hand, it has been also observed that in the human muscle metformin reduces the expression of mTORC1-related genes in older individuals with impaired glucose tolerance [131], leading to a possible decrease in muscle protein synthesis or increased autophagy [132].

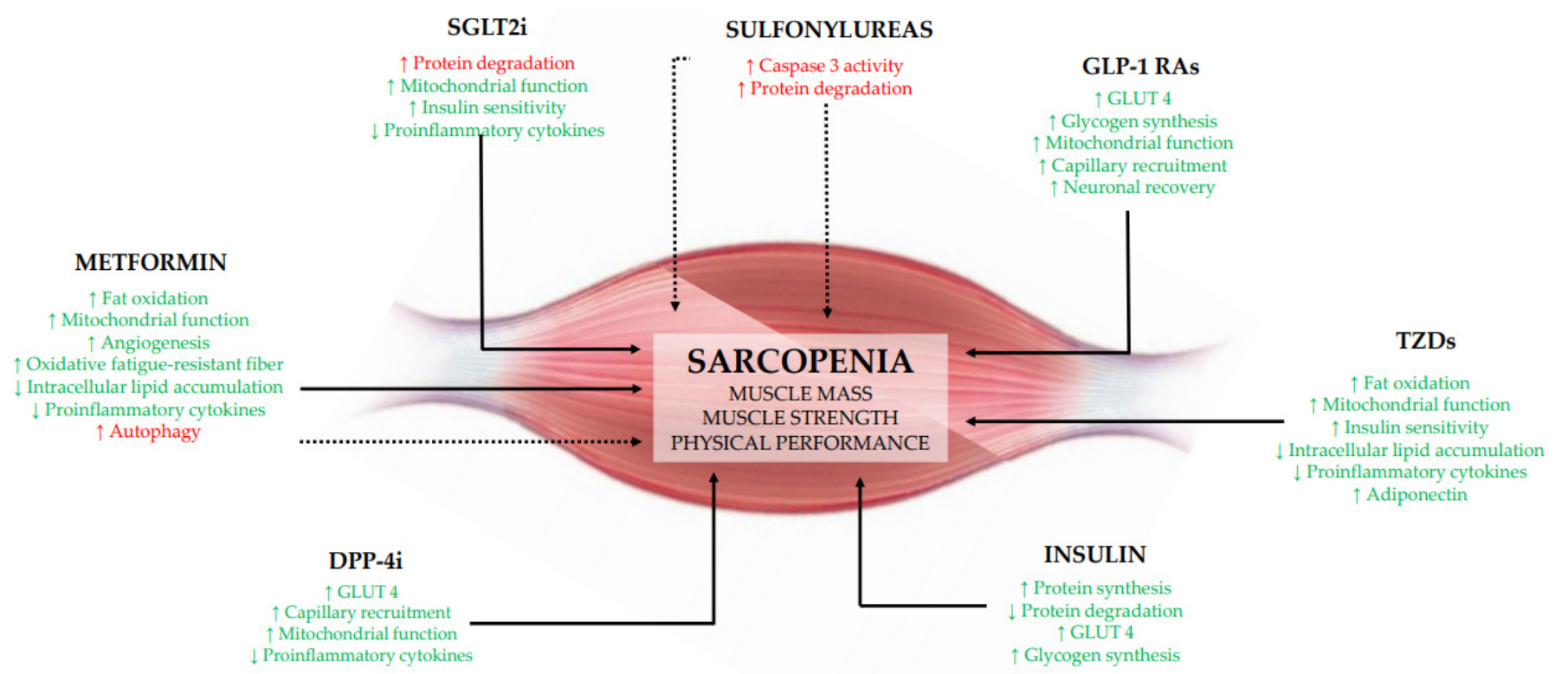

Figure 1. Plausible mechanisms by which glucose-lowering drugs might impact on sarcopenia acting on sarcopenia. DPP-4i, dipeptidyl peptidase-4 inhibitors; GLP-1 Ras, glucagon-like peptide-1 receptor agonists; GLUT4, glucose transporter type 4; SGLT2i, sodium-glucose transport protein 2 inhibitors; TZDs, thiazolidinediones. $\uparrow$, increase; $\downarrow$, decrease. Green color and continue lines indicate a beneficial effect on sarcopenia; red color and dotted lines indicate a detrimental effect on sarcopenia.

\subsection{Thiazolidinediones}

TZDs improve insulin sensitivity through activation of the peroxisome proliferatoractivated receptor- $\gamma$ which facilitates differentiation of mesenchymal stem cells into adipocytes, promotes lipogenesis in peripheral adipocytes, decreases hepatic and peripheral triglycerides, decreases activity of visceral adipocytes, and increases adiponectin production. These primary effects of TZDs markedly ameliorate insulin resistance, decreasing insulin requirement and positively impact on the features of the metabolic syndrome [133].

TZDs might increase plasma levels of adiponectin and expression of its receptors, activates AMPK and acetyl-CoA carboxylase in muscle, and increases expression of genes involved in mitochondrial function and fat oxidation, promoting an improvement in mitochondrial respiratory capacity in skeletal muscle [134]. The expression of these genes may lead to a decrease in toxic intracellular lipid metabolites, thus improving the insulin signaling in muscle and enhancing insulin sensitivity [135] (Figure 1). 


\subsection{Sulfonylureas}

Sulfonylureas increase the release of insulin through the stimulation of pancreatic $\beta$-cells. By binding to a subunit of potassium ATP-dependent channels, which consists of a sulfonylurea receptor-1 and an inward-rectifier potassium ion channel, this class of glucoselowering drugs inhibit the cellular release of potassium, leading to cell depolarization. As a result, an inflow of calcium into the cell occurs which causes an increase in insulin exocytosis [136].

Looking at possible mechanisms, we can only speculate using data from in vitro studies. Sulfonylurea induced atrophy in rat skeletal muscles by reducing the protein content in the flexor digitorum brevis [93]; the activation of the atrophic signaling was induced through caspase-3-dependent or independent pathways [137] (Figure 1).

\subsection{Dipeptidyl Peptidase-4 Inhibitors}

DPP-4i are glucose-lowering drugs that rapidly and specifically inhibit DPP-4 activity. DDP-4 is the main enzyme involved in the biochemical pathways affecting both the degradation and inactivation of the gastrointestinal hormones GLP-1 and gastric inhibitory polypeptide (GIP). By preventing this, DPP-4i enhance active GLP-1 and GIP levels by 2 to 3 -fold following a meal, promoting the secretion of insulin and the inhibition of glucagon release [138].

The mechanism by which DPP-4i may increase muscle mass is unclear and could be related to their ability of enhancing GLP-1 action or to the inhibition of DPP-4 activity per se or both. In animal models, DPP-4i promoted GLUT4 expression in the soleus and gastrocnemius muscles [139] and improved skeletal muscle glucose uptake by enhancing capillary recruitment and interstitial insulin concentrations [140]. Furthermore, an improvement in mitochondrial biogenesis and exercise capacity in skeletal muscle has also been reported [141]. Finally, there is evidence that DPP-4i reduce plasma levels of the inflammatory parameters in humans [142] (Figure 1).

\subsection{Glucagon-Like Peptide-1 Receptor Agonists}

GLP-1 RAs bind with high specificity to the GLP-1 receptor and stimulate glucosedependent insulin release from the pancreatic $\beta$-cells. GLP-1 improves the glycemic control by enhancing both synthesis and secretion of insulin via the glucose-dependent pancreatic insulin pathways; it also induces, via a paracrine route, the inhibition of glucagon secretion from pancreatic $\alpha$-cells. Other effects of GLP- 1 are the slowing down of the rate of endogenous glucose production, the retardation of gastric emptying, thus preventing large post-meal glycemic increments, the promotion of satiety, and the reduction in the caloric intake and body weight [143].

The potential mechanisms regarding the effect of GLP-1 RAs on skeletal muscle remain a matter of debate. GLP-1 RAs could increase the expression of GLUT4 gene, glucose uptake, and glycogen synthesis in skeletal muscle cells [144]. Again, GLP-1 RAs promote oxygen consumption and favor insulin sensitivity in skeletal muscle [145]. Furthermore, the infusion of GLP-1 RAs increases microvascular recruitment in human skeletal muscle independent of insulin, which may potentiate local insulin action [146]. Interestingly, GLP-1 RAs might facilitate neuronal recovery after the crush nerve, leading to an improvement in muscle health [147] (Figure 1).

\subsection{Sodium-Glucose Transport Protein 2 Inhibitors}

The SGLT2 are carrier proteins expressed in the proximal convoluted tubule of the kidney, where they significantly contribute to the reabsorption of approximately $90 \%$ of renal glucose. Thus, SGLT2i exert their glucose-lowering effects by reducing the renal threshold for glucose reabsorption and inducing glucose urinary excretion. However, they increase hepatic glucose production, glucagon secretion, ketogenesis, and lipid oxidation, which may promote reduction in body fat mass, including visceral fat [148]. Muscle mass loss may represent a major concern with the use of SGLT2i, and different mechanisms may 
explain this effect: the reduction in insulin levels and increase in glucagon levels promoted by SGLT2 lead to the activation of gluconeogenesis, which might promote not only lipolysis in the adipose tissue, but also proteolysis in the skeletal muscle suppling amino acids to the liver and leading to sarcopenia [148]. However, the effect of SGLT2i in the long term may improve insulin sensitivity counteracting muscle catabolism and affecting skeletal muscle function and quality [149]. With respect to the beneficial effects of SGLT2i on maximal handgrip strength, a possible mechanism might be the effects on chronic inflammation and adipokine profile [150], as well as improvement in mitochondrial function [151] (Figure 1).

\subsection{Insulin}

Epidemiological evidence and the clinical trial available suggest the beneficial association between insulin use and parameters of sarcopenia $[87,95,96]$, indicating that a possible prescription of exogenous insulin could improve insulin signaling in the skeletal muscle, promote protein synthesis, and protect against the loss of muscle mass among patients with diabetes, especially those with a long duration of diabetes.

Insulin is an anabolic hormone that increases protein synthesis in the muscle, promotes glucose uptake and glycogen synthesis [152] (Figure 1). Furthermore, physiological hyperinsulinemia stimulates muscle protein synthesis and anabolism in young individuals [153]. This effect is blunted in older people and in those with insulin resistance [153], suggesting that supraphysiological hyperinsulinemia could be necessary for the anabolic effect of insulin in elderly individuals [154].

\section{Conclusions}

Prevention of muscle quantity/quality loss might represent an important aim for elderly patients with T2DM, both in relation to the relatively high frequency of sarcopenia, and in consideration of the impact of this condition on the quality of life.

Prevention of sarcopenia is a major area of research activity, and observational epidemiological studies have identified important risk factors such as older age, genetic factors, gender, ethnical background, low socioeconomic status, low physical activity, poor diet [13-15], sleep disturbance [16,17], comorbidities and pharmacological intervention $[14,15]$. Further risk factors in elderly people with T2DM were diabetes duration and microvascular complications [32,99].

As lifestyle factors are reversible, while age-related systemic changes are largely unmodifiable, it is important to raise public awareness of their impact on the development of sarcopenia.

Physical activity, in particular resistance-based training, and good nutrition represent the cornerstones of healthy ageing [15]. Although the effects of nutritional interventions on muscular outcomes in elderly people have been less carefully evaluated than those of exercise, more data are accumulating in support of the capacity of appropriate nutrition to positively influence muscle mass and function, both alone and in combination with exercise training $[15,155]$. Evidence, to date, points towards important roles for an adequate intake of protein, vitamin D, antioxidants, and long-chain polyunsaturated fatty acids [42-45].

Beyond lifestyle changes, in recent years, interest of clinicians, nutritionists and scientists has been particularly focused on the role played by glucose-lowering drugs in the modulation of sarcopenia in people with diabetes. In fact, information on this issue may be relevant in order to better identify patients at higher risk for this condition, and to implement appropriate changes in the choice of the glucose-lowering drug, together with lifestyle modifications, in order to reduce the risk of sarcopenia in those who are particularly prone to develop it and, in particular, elderly patients.

Different glucose-lowering drugs are available for the treatment of T2DM, and the cornerstone of diabetes pharmacological approach is represented by the ability to account for the heterogeneous characteristics of the patients, individualizing treatment targets and goals. Among these goals, increasing attention has been paid to the need to reduce the risk 
of sarcopenia in elderly patients in whom this condition is emerging as a third category of diabetes complications that can lead to a clinical and significant disability.

The evidence presented in this narrative review shows that glucose-lowering drugs could play a role in sarcopenia in T2DM patients with some differences between them in relation to their mechanisms of action.

However, beyond a drug-/class-specific effect we cannot exclude a possible effect of glucose-lowering drugs on markers of sarcopenia mediated also by a better glycemic control. In this regard, in the few controlled studies available, the improvement in glycemic control at the end of treatment was similar among the various treatment groups, suggesting that the observed effect on the parameters of sarcopenia could be related to the drug/class specific effect $[66-68,72,74,75]$. On the other hand, in one trial, the improvement of glycemic control in the SGLT2i vs. control was not followed by an improvement in SMM [81]. Again, in two studies without a control group a correlation analysis between the improvement in glycemic control and the observed effect on the parameters of sarcopenia didn't show statistical significance $[78,84]$. Therefore, although it seems reasonable to assume that the impact of glucose-lowering drugs on markers of sarcopenia may be partly mediated by an improvement in blood glucose control, the available evidence still supports a specific and direct role of some of them independently of their glucose-lowering activity.

At this point, it is important to underline the limitations of studies discussed in this review, such as the single arm design of many trials, the small sample size, the absence of information regarding dietary habits and physical activity of the participants that could impact on sarcopenia, and the large inhomogeneity of the study populations in terms of age and BMI. Furthermore, parameters of sarcopenia were secondary outcomes in some studies. Importantly, many different methods were used to diagnose sarcopenia that are hardly comparable with each other. The muscle quantity/mass has been reported in the various studies as total SMM, as ASM or as muscle cross-sectional area of specific muscle groups or body locations. In order to overcome this limitation, as seen in Table 1, we focused on SMI — calculated as ASM/height ${ }^{2}$ or SMM/height ${ }^{2}$ —or SMM evaluated by dual-energy X-ray absorptiometry or bioelectrical impedance analysis in all trials. For the skeletal muscle strength, we have reported data coming from standardized evaluation performed by a calibrated handheld dynamometer.

Considering all the methodological problems linked to the identification of reliable parameters for the diagnosis of sarcopenia, and the inaccuracies in the design of the available trials, there are only few conclusions that are reliable enough to support clinical recommendations. In particular, it seems well established that insulin is able to reduce the risk of sarcopenia, while DPP-4i might have a neutral impact on it. Data on other glucose-lowering drugs are controversial and inconclusive. However, emerging new data indicate that treatment with SGLT2i may contribute to a reduction in SMI and SMM. These untoward effects of SGLT2i at the muscle level contrast with the multiple beneficial effects of this drug on other relevant and frequent diabetes complications at the level of the kidney and the heart [46-49].

Nevertheless, on the basis of the evidence reviewed in this paper, it seems appropriate to consider limiting the use of SGLT2i in elderly patients with sarcopenia or at high risk for this condition, unless other clinical conditions justify the need to use them; in this case, a very accurate monitoring of the parameters that characterize sarcopenia would be necessary in order to be able to implement an appropriate treatment, consisting in physical activity, in particular resistance-based training, and good nutrition, in the presence of any derangement.

Further well-designed trials, with large sample sizes, including representative cohorts of elderly patients and with a sufficiently long duration are needed to better elucidate the effects of glucose-lowering drugs on sarcopenia; obviously, for these studies, it is of paramount importance that they take into account all the clinical/instrumental features and pathophysiological mechanisms relevant for the evaluation of this condition. A further interesting aspect to explore should be the impact of a multifactorial intervention combining 
physical activity and appropriate dietary choices with the most suitable glucose-lowering drugs on muscle mass and function in elderly patients with T2DM, in the perspective that this approach may have a clinically relevant impact on the prevention of sarcopenia in elderly patients at risk for this condition.

Author Contributions: G.D.P. and G.R. conceptualized the manuscript. E.M. and A.I. conducted literature research. E.M. and G.D.P. wrote the draft of the review. G.D.P. review and editing; G.R. provided relevant intellectual contribution to the development of the review. All authors have read and agreed to the published version of the manuscript.

Funding: This research received no external funding.

Institutional Review Board Statement: Not applicable.

Informed Consent Statement: Not applicable.

Data Availability Statement: Not applicable.

Conflicts of Interest: The authors declare no conflict of interest.

\section{References}

1. United Nations, Department of Economic and Social Affairs PD. World Population Ageing. 2020. Available online: https: / / www.un.org/development/desa/pd/news/world-population-ageing-2020-highlights (accessed on 5 June 2021).

2. Filippin, L.I.; Teixeira, V.N.; da Silva, M.P.; Miraglia, F.; da Silva, F.S. Sarcopenia: A predictor of mortality and the need for early diagnosis and intervention. Aging Clin. Exp. Res. 2015, 27, 249-254. [CrossRef]

3. Goodpaster, B.H.; Park, S.W.; Harris, T.B.; Kritchevsky, S.B.; Nevitt, M.; Schwartz, A.V.; Simonsick, E.M.; Tylavsky, F.A.; Visser, M.; Newman, A.B. The loss of skeletal muscle strength, mass, and quality in older adults: The health, aging and body composition study. J. Gerontol. A. Biol. Sci. Med. Sci. 2006, 61, 1059-1064. [CrossRef] [PubMed]

4. Cao, L.; Morley, L.E. Sarcopenia Is Recognized as an Independent Condition by an International Classification of Disease, Tenth Revision, Clinical Modification (ICD-10-CM) Code. J. Am. Med. Dir. Assoc. 2016, 17, 675-677. [CrossRef]

5. Cruz-Jentoft, A.J.; Bahat, G.; Bauer, J.; Boirie, Y.; Bruyère, O.; Cederholm, T.; Cooper, C.; Landi, F.; Rolland, Y.; Sayer, A.A.; et al. Writing Group for the European Working Group on Sarcopenia in Older People 2 (EWGSOP2).; and the Extended Group for EWGSOP2. Sarcopenia: Revised European consensus on definition and diagnosis. Age Ageing 2019, 48, 16-31. [CrossRef] [PubMed]

6. Chen, L.K.; Woo, J.; Assantachai, P.; Auyeung, T.W.; Chou, M.Y.; Iijima, K.; Jang, H.C.; Kang, L.; Kim, M.; Kim, S.; et al. Asian Working Group for Sarcopenia: 2019 Consensus Update on Sarcopenia Diagnosis and Treatment. J. Am. Med. Dir. Assoc. 2020, $21,300-307$. [CrossRef]

7. Kera, T.; Kawai, H.; Hirano, H.; Kojima, M.; Watanabe, Y.; Motokawa, K.; Fujiwara, Y.; Ihara, K.; Kim, H.; Obuchi, S. Defnition of respiratory sarcopenia with peak expiratory fow rate. J. Am. Med. Direct. Assoc. 2019, 20, 1021-1025. [CrossRef] [PubMed]

8. Nagano, A.; Wakabayashi, H.; Maeda, K.; Kokura, Y.; Miyazaki, S.; Mori, T.; Fujiwara, D. Respiratory Sarcopenia and Sarcopenic Respiratory Disability: Concepts, Diagnosis, and Treatment. J. Nutr. Health. Aging. 2021, 25, 507-515. [CrossRef] [PubMed]

9. Buchman, A.S.; Boyle, P.A.; Wilson, R.S.; Gu, L.; Bienias, J.L.; Bennett, D.A. Pulmonary function, muscle strength and mortality in old age. Mech. Ageing. Dev. 2008, 129, 625-631. [CrossRef]

10. Visser, M.; Schaap, L.A. Consequences of sarcopenia. Clin. Geriatr. Med. 2011, 27, 387-399. [CrossRef] [PubMed]

11. Okazaki, T.; Ebihara, S.; Mori, T.; Izumi, S.; Ebihara, T. Association between sarcopenia and pneumonia in older people. Geriatr. Gerontol. Int. 2020, 20,7-13. [CrossRef] [PubMed]

12. Mayhew, A.J.; Amog, K.; Phillips, S.; Parise, G.; McNicholas, P.D.; de Souza, R.J.; Thabane, L.; Raina, P. The prevalence of sarcopenia in community-dwelling older adults, an exploration of differences between studies and within definitions: A systematic review and meta-analyses. Age Ageing 2019, 48, 48-56. [CrossRef] [PubMed]

13. Kwak, D.; Thompson, L.V. Frailty: Past, present, and future? SMHS 2021, 3, 1-10.

14. Dennison, E.M.; Sayer, A.A.; Cooper, C. Epidemiology of sarcopenia and insight into possible therapeutic targets. Nat. Rev. Rheumatol. 2017, 13, 340-347. [CrossRef] [PubMed]

15. Cruz-Jentoft, A.J.; Sayer, A.A. Sarcopenia. Lancet 2019, 393, 2636-2646. [CrossRef]

16. Pourmotabbed, A.; Ghaedi, E.; Babaei, A.; Mohammadi, H.; Khazaie, H.; Jalili, C.; Symonds, M.E.; Moradi, S.; Miraghajani, M. Sleep duration and sarcopenia risk: A systematic review and dose-response meta-analysis. Sleep Breath 2020, 24, $1267-1278$. [CrossRef]

17. Prokopidis, K.; Dionyssiotis, Y. Effects of sleep deprivation on sarcopenia and obesity: A narrative review of randomized controlled and crossover trials. J. Frailty Sarcopenia Falls 2021, 6, 50-56. [CrossRef]

18. Steffl, M.; Bohannon, R.W.; Petr, M.; Kohlikova, E.; Holmerova, I. Alcohol consumption as a risk factor for sarcopenia-a meta-analysis. BMC Geriatr. 2016, 16, 16-99. [CrossRef] 
19. Steffl, M.; Bohannon, R.W.; Petr, M.; Kohlikova, E.; Holmerova, I. Relation between cigarette smoking and sarcopenia: Metaanalysis. Physiol. Res. 2015, 64, 419-426. [CrossRef]

20. Lee, J.S.; Auyeung, T.W.; Kwok, T.; Lau, E.M.; Leung, P.C.; Woo, J. Associated factors and health impact of sarcopenia in older Chinese men and women: A cross-sectional study. Gerontology 2007, 53, 404-410. [CrossRef]

21. Tournadre, A.; Vial, G.; Capel, F.; Soubrier, M.; Boirie, Y. Sarcopenia. Jt. Bone Spine 2019, 86, 309-314. [CrossRef]

22. Guillet, C.; Zangarelli, A.; Gachon, P.; Morio, B.; Giraudet, C.; Rousset, P.; Boirie, Y. Whole body protein breakdown is less inhibited by insulin, but still responsive to amino acid, in nondiabetic elderly subjects. J. Clin. Endocrinol. Metab. 2004, 89, 6017-6024. [CrossRef]

23. Martín, A.I.; Priego, T.; López-Calderón, A. Hormones and Muscle Atrophy. Adv. Exp. Med. Biol. 2018, 1088, 207-233. [PubMed]

24. Carter, C.S.; Justice, J.N.; Thompson, L. Lipotoxicity, aging, and muscle contractility: Does fiber type matter? GeroScience 2019, 41, 297-308. [CrossRef] [PubMed]

25. Shou, J.; Chen, P.J.; Xiao, W.H. Mechanism of increased risk of insulin resistance in aging skeletal muscle. Diabetol. Metab. Syndr. 2020, 12, 14. [CrossRef] [PubMed]

26. Picca, A.; Calvani, R.; Bossola, M.; Allocca, E.; Menghi, A.; Pesce, V.; Lezza, A.; Bernabei, R.; Landi, F.; Marzetti, E. Update on mitochondria and muscle aging: All wrong roads lead to sarcopenia. Biol. Chem. 2018, 399, 421-436. [CrossRef]

27. Tuttle, C.; Thang, L.; Maier, A.B. Markers of inflammation and their association with muscle strength and mass: A systematic review and meta-analysis. Ageing Res. Rev. 2020, 64, 101185. [CrossRef] [PubMed]

28. McCormick, R.; Vasilaki, A. Age-related changes in skeletal muscle: Changes to life-style as a therapy. Biogerontology 2018, 19, 519-536. [CrossRef]

29. Rygiel, K.A.; Picard, M.; Turnbull, D.M. The ageing neuromuscular system and sarcopenia: A mitochondrial perspective. J. Physiol. 2016, 594, 4499-4512. [CrossRef]

30. American Diabetes Association. 12. Older Adults: Standards of Medical Care in Diabetes. Diabetes Care 2020, 43 (Suppl. 1), S152-S162. [CrossRef]

31. Anagnostis, P.; Gkekas, N.K.; Achilla, C.; Pananastasiou, G.; Taouxidou, P.; Mitsiou, M.; Kenanidis, E.; Potoupnis, M.; Tsiridis, E.; Goulis, D.G. Type 2 Diabetes Mellitus is Associated with Increased Risk of Sarcopenia: A Systematic Review and Meta-analysis. Calcif Tissue Int. 2020, 107, 453-463. [CrossRef]

32. Izzo, A.; Massimino, E.; Riccardi, G.; Della Pepa, G. A Narrative Review on Sarcopenia in Type 2 Diabetes Mellitus: Prevalence and Associated Factors. Nutrients 2021, 13, 183. [CrossRef]

33. Veronese, N.; Stubbs, B.; Punzi, L.; Soysal, P.; Incalzi, R.A.; Saller, A.; Maggi, S. Effect of nutritional supplementations on physical performance and muscle strength parameters in older people: A systematic review and meta-analysis. Ageing Res. Rev. 2019, 51, 48-54. [CrossRef]

34. Dodds, R.M.; Syddall, H.E.; Cooper, R.; Benzeval, M.; Deary, I.J.; Dennison, E.M.; Der, G.; Gale, C.R.; Inskip, H.M.; Jagger, C.; et al. Grip strength across the life course: Normative data from twelve British studies. PLoS ONE 2014, 9, e113637. [CrossRef]

35. Beaudart, C.; Dawson, A.; Shaw, S.C.; Harvey, N.C.; Kanis, J.A.; Binkley, N.; Reginster, J.Y.; Chapurlat, R.; Chan, D.C.; Bruyère, O.; et al. IOF-ESCEO Sarcopenia Working Group. Nutrition and physical activity in the prevention and treatment of sarcopenia: Systematic review. Osteoporos. Int. 2017, 28, 1817-1833. [CrossRef]

36. Lee, S.Y.; Tung, H.H.; Liu, C.Y.; Chen, L.K. Physical Activity and Sarcopenia in the Geriatric Population: A Systematic Review. J. Am. Med. Dir. Assoc. 2018, 19, 378-383. [CrossRef]

37. Shaw, S.C.; Dennison, E.M.; Cooper, C. Epidemiology of Sarcopenia: Determinants Throughout the Lifecourse. Calcif. Tissue Int. 2017, 101, 229-247. [CrossRef]

38. Vlietstra, L.; Hendrickx, W.; Waters, D.L. Exercise interventions in healthy older adults with sarcopenia: A systematic review and meta-analysis. Australas. J. Ageing 2018, 37, 169-183. [CrossRef] [PubMed]

39. Lozano-Montoya, I.; Correa-Pérez, A.; Abraha, I.; Soiza, R.L.; Cherubini, A.; O’Mahony, D.; Cruz-Jentoft, A.J. Nonpharmacological interventions to treat physical frailty and sarcopenia in older patients: A systematic overview-the SENATOR Project ONTOP Series. Clin. Interv. Aging. 2017, 12, 721-740. [CrossRef]

40. Steffl, M.; Bohannon, R.W.; Sontakova, L.; Tufano, J.J.; Shiells, K.; Holmerova, I. Relationship between sarcopenia and physical activity in older people: A systematic review and meta-analysis. Clin. Interv. Aging 2017, 12, 835-845. [CrossRef] [PubMed]

41. Hovanec, N.; Sawant, A.; Overend, T.J.; Petrella, R.J.; Vandervoort, A.A. Resistance training and older adults with type 2 diabetes mellitus: Strength of the evidence. J. Aging. Res. 2012, 2012, 284635. [CrossRef] [PubMed]

42. Ganapathy, A.; Nieves, J.W. Nutrition and Sarcopenia-What Do We Know? Nutrients 2020, 12, 1755. [CrossRef]

43. McKendry, J.; Currier, B.S.; Lim, C.; Mcleod, J.C.; Thomas, A.; Phillips, S.M. Nutritional Supplements to Support Resistance Exercise in Countering the Sarcopenia of Aging. Nutrients 2020, 12, 2057. [CrossRef] [PubMed]

44. Bloom, I.; Shand, C.; Cooper, C.; Robinson, S.; Baird, J. Diet Quality and Sarcopenia in Older Adults: A Systematic Review. Nutrients 2018, 10, 308. [CrossRef] [PubMed]

45. Robinson, S.M.; Reginster, J.Y.; Rizzoli, R.; Shaw, S.C.; Kanis, J.A.; Bautmans, I.; Bischoff-Ferrari, H.; Bruyère, O.; Cesari, M.; Dawson-Hughes, B.; et al. ESCEO working group. Does nutrition play a role in the prevention and management of sarcopenia? Clin. Nutr. 2018, 37, 1121-1132. [CrossRef] [PubMed]

46. Tsapas, A.; Avgerinos, I.; Karagiannis, T.; Malandris, K.; Manolopoulos, A.; Andreadis, P.; Liakos, A.; Matthews, D.R.; Bekiari, E. Comparative Effectiveness of Glucose-Lowering Drugs for Type 2 Diabetes: A Systematic Review and Network Meta-analysis. Ann. Intern. Med. 2020, 173, 278-286. [CrossRef] 
47. Lee, C.G.; Cefalu, W.T. The Right Diabetes Medication for the Right Patient for the Right Outcome: Can a Network Meta-analysis Help Us Decide? Ann. Intern. Med. 2020, 173, 311-312. [CrossRef] [PubMed]

48. American Diabetes Association. 9. Pharmacologic Approaches to Glycemic Treatment: Standards of Medical Care in Diabetes2021. Diabetes Care 2021, 44, S111-S124. [CrossRef]

49. Mosenzon, O.; Del Prato, S.; Schechter, M.; Leiter, L.A.; Ceriello, A.; DeFronzo, R.A.; Raz, I. From glucose lowering agents to disease/diabetes modifying drugs: A "SIMPLE" approach for the treatment of type 2 diabetes. Cardiovasc. Diabetol 2021, 20, 92. [CrossRef]

50. Patti, A.M.; Rizvi, A.A.; Giglio, R.V.; Stoian, A.P.; Ligi, D.; Mannello, F. Impact of Glucose-Lowering Medications on Cardiovascular and Metabolic Risk in Type 2 Diabetes. J. Clin. Med. 2020, 9, 912. [CrossRef] [PubMed]

51. Baethge, C.; Goldbeck-Wood, S.; Mertens, S. SANRA-a scale for the quality assessment of narrative review articles. Res. Integr. Peer. Rev. 2019, 4, 5. [CrossRef]

52. Beaudart, C.; McCloskey, E.; Bruyère, O.; Cesari, M.; Rolland, Y.; Rizzoli, R.; Araujo de Carvalho, I.; Amuthavalli Thiyagarajan, J.; Bautmans, I.; Bertière, M.C.; et al. Sarcopenia in daily practice: Assessment and management. BMC Geriatr. 2016, 16, 170. [CrossRef] [PubMed]

53. Buckinx, F.; Landi, F.; Cesari, M.; Fielding, R.A.; Visser, M.; Engelke, K.; Maggi, S.; Dennison, E.; Al-Daghri, N.M.; Allepaerts, S.; et al. Pitfalls in the measurement of muscle mass: A need for a reference standard. J. Cachexia Sarcopenia Muscle 2018, 9, 269-278. [CrossRef] [PubMed]

54. Rossi, A.P.; Fantin, F.; Micciolo, R.; Bertocchi, M.; Bertassello, P.; Zanandrea, V.; Zivelonghi, A.; Bissoli, L.; Zamboni, M. Identifying sarcopenia in acute care setting patients. J. Am. Med. Dir. Assoc. 2014, 15, e7-e12. [CrossRef] [PubMed]

55. Maggio, M.; Ceda, G.P.; Ticinesi, A.; De Vita, F.; Gelmini, G.; Costantino, C.; Meschi, T.; Kressig, R.W.; Cesari, M.; Fabi, M.; et al. Instrumental and Non-Instrumental Evaluation of 4-Meter Walking Speed in Older Individuals. PLoS ONE 2016, 11, e0153583. [CrossRef]

56. Available online: https://www.nia.nih.gov/research/labs/leps/short-physical-performance-battery-sppb.ShortPhysic alPerformanceBattery (accessed on 5 June 2021).

57. Podsiadlo, D.; Richardson, S. The timed "Up \& Go": A test of basic functional mobility for frail elderly persons. J. Am. Geriatr. Soc. 1991, 39, 142-148. [PubMed]

58. Lee, C.G.; Boyko, E.J.; Barrett-Connor, E.; Miljkovic, I.; Hoffman, A.R.; Everson-Rose, S.A.; Lewis, C.E.; Mannen Cawthon, P.; Strotmeyer, E.S.; Orwoll, E.S. Osteoporotic Fractures in Men (MrOS) Study Research Group. Insulin sensitizers may attenuate lean mass loss in older men with diabetes. Diabetes Care 2011, 34, 2381-2386. [CrossRef] [PubMed]

59. Lee, C.G.; Schwartz, A.V.; Yaffe, K.; Hillier, T.A.; LeBlanc, E.S.; Cawthon, P.M. for the Study of Osteoporotic Fractures Research Group. Changes in Physical Performance in Older Women According to Presence and Treatment of Diabetes Mellitus. J. Am. Geriatr. Soc. 2013, 61, 1872-1878. [CrossRef]

60. Bouchi, R.; Fukuda, T.; Takeuchi, T.; Minami, I.; Yoshimoto, T.; Ogawa, Y. Sarcopenia is associated with incident albuminuria in patients with type 2 diabetes: A retrospective observational study. J. Diabetes Investig. 2017, 8, 783-787. [CrossRef] [PubMed]

61. Cui, M.; Gang, X.; Wang, G.; Xiao, X.; Li, Z.; Jiang, Z.; Wang, G. A cross-sectional study: Associations between sarcopenia and clinical characteristics of patients with type 2 diabetes. Medicine 2020, 99, e18708. [CrossRef]

62. Fukuoka, Y.; Narita, T.; Fujita, H.; Morii, T.; Sato, T.; Sassa, M.H.; Yamada, Y. Importance of physical evaluation using skeletal muscle mass index and body fat percentage to prevent sarcopenia in elderly Japanese diabetes patients. J. Diabetes Investig. 2019, 10, 322-330. [CrossRef]

63. Yang, R.; Zhang, Y.; Shen, X.; Yan, S. Sarcopenia associated with renal function in the patients with type 2 diabetes. Diabetes Res. Clin. Pract. 2016, 118, 121-129. [CrossRef]

64. Aghili, R.; Malek, M.; Valojerdi, A.E.; Banazadeh, Z.; Najafi, L.; Khamseh, M.E. Body composition in adults with newly diagnosed type 2 diabetes: Effects of metformin. J. Diabetes Metab. Disord. 2014, 13, 88. [CrossRef] [PubMed]

65. Sexton, P.; Metcalf, P.; Kolbe, J. Respiratory effects of insulin sensitisation with metformin: A prospective observational study. COPD 2014, 11, 133-142. [CrossRef]

66. Koshizaka, M.; Ishikawa, K.; Ishibashi, R.; Takahashi, S.; Sakamoto, K.; Yokoh, H.; Baba, Y.; Ide, S.; Ide, K.; Ishikawa, T.; et al. Comparison of Visceral Fat Reduction by Ipragliflozin and Metformin in Elderly Type 2 Diabetes Patients: Sub-Analysis of a Randomized-Controlled Study. Diabetes Ther. 2021, 12, 183-196. [CrossRef]

67. Ishii, S.; Nagai, Y.; Kato, H.; Fukuda, H.; Tanaka, Y. Effect of the Dipeptidyl Peptidase-4 Inhibitor Sitagliptin on Muscle Mass and the Muscle/Fat Ratio in Patients with Type 2 Diabetes. J. Clin. Med. Res. 2020, 12, 122-126. [CrossRef] [PubMed]

68. Yajima, T.; Yajima, K.; Takahashi, H.; Yasuda, K. The effect of dulaglutide on body composition in type 2 diabetes mellitus patients on hemodialysis. J. Diabetes Complications 2018, 32, 759-763. [CrossRef] [PubMed]

69. Perna, S.; Guido, D.; Bologna, C.; Solerte, S.B.; Guerriero, F.; Isu, A.; Rondanelli, M. Liraglutide and obesity in elderly: Efficacy in fat loss and safety in order to prevent sarcopenia. A perspective case series study. Aging Clin. Exp. Res. 2016, 28, 1251-1257. [CrossRef] [PubMed]

70. Rondanelli, M.; Perna, S.; Astrone, P.; Grugnetti, A.; Solerte, S.B.; Guido, D. Twenty-four-week effects of liraglutide on body composition, adherence to appetite, and lipid profile in overweight and obese patients with type 2 diabetes mellitus. Patient Prefer. Adherence 2016, 10, 407-413. 
71. Hong, J.Y.; Park, K.Y.; Kim, B.J.; Hwang, W.M.; Kim, D.H.; Lim, D.M. Effects of Short-Term Exenatide Treatment on Regional Fat Distribution, Glycated Hemoglobin Levels, and Aortic Pulse Wave Velocity of Obese Type 2 Diabetes Mellitus Patients. Endocrinol. Metab. 2016, 31, 80-85. [CrossRef]

72. Tsurutani, Y.; Nakai, K.; Inoue, K.; Azuma, K.; Mukai, S.; Maruyama, S.; Iizuka, T.; Matsuzawa, Y.; Saito, J.; Omura, M.; et al. Comparative study of the effects of ipragliflozin and sitagliptin on multiple metabolic variables in Japanese patients with type 2 diabetes: A multicentre, randomized, prospective, open-label, active-controlled study. Diabetes Obes. Metab. 2018, 20, 2675-2679. [CrossRef]

73. Sano, M.; Meguro, S.; Kawai, T.; Suzuki, Y. Increased grip strength with sodium-glucose cotransporter 2. J. Diabetes 2016, 8, 736-737. [CrossRef] [PubMed]

74. Shimizu, M.; Suzuki, K.; Kato, K.; Jojima, T.; Iijima, T.; Murohisa, T.; Iijima, M.; Takekawa, H.; Usui, I.; Hiraishi, H.; et al. Evaluation of the effects of dapagliflozin, a sodium-glucose co-transporter-2 inhibitor, on hepatic steatosis and fibrosis using transient elastography in patients with type 2 diabetes and non-alcoholic fatty liver disease. Diabetes Obes. Metab. 2019, 21, 285-292. [CrossRef] [PubMed]

75. Sugiyama, S.; Jinnouchi, H.; Kurinami, N.; Hieshima, K.; Yoshida, A.; Jinnouchi, K.; Nishimura, H.; Suzuki, T.; Miyamoto, F.; Kajiwara, K.; et al. Dapagliflozin Reduces Fat Mass without Affecting Muscle Mass in Type 2 Diabetes. J. Atheroscler Thromb 2018, 25, 467-476. [CrossRef] [PubMed]

76. Yamakage, H.; Tanaka, M.; Inoue, T.; Odori, S.; Kusakabe, T.; Satoh-Asahara, N. Effects of dapagliflozin on the serum levels of fibroblast growth factor 21 and myokines and muscle mass in Japanese patients with type 2 diabetes: A randomized, controlled trial. J. Diabetes Investig. 2020, 11, 653-661. [CrossRef] [PubMed]

77. Tobita, H.; Sato, S.; Miyake, T.; Ishihara, S.; Kinoshita, Y. Effects of Dapagliflozin on Body Composition and Liver Tests in Patients with Nonalcoholic Steatohepatitis Associated with Type 2 Diabetes Mellitus: A Prospective, Open-label, Uncontrolled Study. Curr. Ther. Res. Clin. Exp. 2017, 87, 13-19. [CrossRef]

78. Sasaki, T.; Sugawara, M.; Fukuda, M. Sodium-glucose cotransporter 2 inhibitor-induced changes in body composition and simultaneous changes in metabolic profile: 52-week prospective LIGHT (Luseogliflozin: The Components of Weight Loss in Japanese Patients with Type 2 Diabetes Mellitus) Study. J. Diabetes Investig. 2019, 10, 108-117. [CrossRef]

79. Bouchi, R.; Terashima, M.; Sasahara, Y.; Asakawa, M.; Fukuda, T.; Takeuchi, T.; Nakano, Y.; Murakami, M.; Minami, I.; Izumiyama, H.; et al. Luseogliflozin reduces epicardial fat accumulation in patients with type 2 diabetes: A pilot study. Cardiovasc. Diabetol. 2017, 16, 32. [CrossRef]

80. Inoue, M.; Hayashi, A.; Taguchi, T.; Arai, R.; Sasaki, S.; Takano, K.; Inoue, Y.; Shichiri, M. Effects of canagliflozin on body composition and hepatic fat content in type 2 diabetes patients with non-alcoholic fatty liver disease. J. Diabetes Investig. 2019, 10, $1004-1011$. [CrossRef]

81. Inoue, H.; Morino, K.; Ugi, S.; Tanaka-Mizuno, S.; Fuse, K.; Miyazawa, I.; Kondo, K.; Sato, D.; Ohashi, N.; Ida, S.; et al. SUMS-ADDIT-1 Research group. Ipragliflozin, a sodium-glucose cotransporter 2 inhibitor, reduces bodyweight and fat mass, but not muscle mass, in Japanese type 2 diabetes patients treated with insulin: A randomized clinical trial. J. Diabetes Investig. 2019, 10, 1012-1021. [CrossRef]

82. Yamamoto, C.; Miyoshi, H.; Ono, K.; Sugawara, H.; Kameda, R.; Ichiyama, M.; Yamamoto, K.; Nomoto, H.; Nakamura, A.; Atsumi, T. Ipragliflozin effectively reduced visceral fat in Japanese patients with type 2 diabetes under adequate diet therapy. Endocr. J. 2016, 63, 589-596. [CrossRef]

83. Iemitsu, K.; Kawata, T.; Iizuka, T.; Takihata, M.; Takai, M.; Nakajima, S.; Minami, N.; Umezawa, S.; Kanamori, A.; Takeda, H.; et al. Efficacy and Safety of Ipragliflozin in Patients with Type 2 Diabetes: ASSIGN-K Study. J. Endocrinol. Metab. 2019, 9, 51-62. [CrossRef]

84. Kato, M.; Sakai, K.; Saito, K.; Tsutsui, K.; Yamashita, S.; Kato, N. Efficacy and safety of ipragliflozin in Japanese patients with type 2 diabetes receiving conventional therapy: Clinical implication of the importance of exercise habits during treatment with ipragliflozin. Diabetol. Int. 2017, 8, 275-285. [CrossRef] [PubMed]

85. Miyake, T.; Yoshida, S.; Furukawa, S.; Sakai, T.; Tada, F.; Senba, H.; Yamamoto, S.; Koizumi, Y.; Yoshida, O.; Hirooka, M.; et al. Ipragliflozin Ameliorates Liver Damage in Non-alcoholic Fatty Liver Disease. Open Med. 2018, 13, 402-409. [CrossRef]

86. Matsuba, R.; Matsuba, I.; Shimokawa, M.; Nagai, Y.; Tanaka, Y. Tofogliflozin decreases body fat mass and improves peripheral insulin resistance. Diabetes Obes. Metab. 2018, 20, 1311-1315. [CrossRef]

87. Ferrari, U.; Then, C.; Rottenkolber, M.; Selte, C.; Seissler, J.; Conzade, R.; Linkohr, B.; Peters, A.; Drey, M.; Thorand, B. Longitudinal association of type 2 diabetes and insulin therapy with muscle parameters in the KORA-Age study. Acta. Diabetol. 2020, 57, $1057-1063$. [CrossRef]

88. Laksmi, P.W.; Setiati, S.; Tamin, T.Z.; Soewondo, P.; Rochmah, W.; Nafrialdi, N.; Prihartono, J. Effect of Metformin on Handgrip Strength, Gait Speed, Myostatin Serum Level, and Health-related Quality of Life: A Double Blind Randomized Controlled Trial among Non-diabetic Pre-frail Elderly Patients. Acta. Med. Indones. 2017, 49, 118-127.

89. Yokota, T.; Kinugawa, S.; Hirabayashi, K.; Suga, T.; Takada, S.; Omokawa, M.; Kadoguchi, T.; Takahashi, M.; Fukushima, A.; Matsushima, S.; et al. Pioglitazone improves whole-body aerobic capacity and skeletal muscle energy metabolism in patients with metabolic syndrome. J. Diabetes Investig. 2017, 8, 535-541. [CrossRef] [PubMed]

90. Bastien, M.; Poirier, P.; Brassard, P.; Arsenault, B.J.; Bertrand, O.F.; Després, J.P.; Costerousse, O.; Piché, M.E. Effect of PPAR $\gamma$ agonist on aerobic exercise capacity in relation to body fat distribution in men with type 2 diabetes mellitus and coronary artery disease: A 1-yr randomized study. Am. J. Physiol. Endocrinol. Metab. 2019, 317, E65-E73. [CrossRef] [PubMed] 
91. Shea, M.K.; Nicklas, B.J.; Marsh, A.P.; Houston, D.K.; Miller, G.D.; Isom, S.; Miller, M.E.; Carr, J.J.; Lyles, M.F.; Harris, T.B.; et al. The effect of pioglitazone and resistance training on body composition in older men and women undergoing hypocaloric weight loss. Obesity 2011, 19, 1636-1646. [CrossRef] [PubMed]

92. Marsh, A.P.; Shea, M.K.; Vance Locke, R.M.; Miller, M.E.; Isom, S.; Miller, G.D.; Nicklas, B.J.; Lyles, M.F.; Carr, J.J.; Kritchevsky, S.B. Resistance training and pioglitazone lead to improvements in muscle power during voluntary weight loss in older adults. $J$. Gerontol. A Biol. Sci. Med. Sci. 2013, 68, 828-836. [CrossRef]

93. Mele, A.; Calzolaro, S.; Cannone, G.; Cetrone, M.; Conte, D.; Tricarico, D. Database search of spontaneous reports and pharmacological investigations on the sulfonylureas and glinides-induced atrophy in skeletal muscle. Pharmacol. Res. Perspect. 2014, 2, e00028. [CrossRef] [PubMed]

94. Rizzo, M.R.; Barbieri, M.; Fava, I.; Desiderio, M.; Coppola, C.; Marfella, R.; Paolisso, G. Sarcopenia in Elderly Diabetic Patients: Role of Dipeptidyl Peptidase 4 Inhibitors. J. Am. Med. Dir. Assoc. 2016, 17, 896-901. [CrossRef]

95. Ida, S.; Nakai, M.; Ito, S.; Ishihara, Y.; Imataka, K.; Uchida, A.; Monguchi, K.; Kaneko, R.; Fujiwara, R.; Takahashi, H.; et al. Association Between Sarcopenia and Mild Cognitive Impairment Using the Japanese Version of the SARC-F in Elderly Patients with Diabetes. J. Am. Med. Dir. Assoc. 2017, 18, 809.e9-809.e13. [CrossRef]

96. Bouchi, R.; Fukuda, T.; Takeuchi, T.; Nakano, Y.; Murakami, M.; Minami, I.; Izumiyama, H.; Hashimoto, K.; Yoshimoto, T.; Ogawa, Y. Insulin Treatment Attenuates Decline of Muscle Mass in Japanese Patients with Type 2 Diabetes. Calcif. Tissue Int. 2017, 101, 1-8. [CrossRef]

97. Cobo, A.; Vázquez, L.A.; Reviriego, J.; Rodríguez-Mañas, L. Impact of frailty in older patients with diabetes mellitus: An overview. Endocrinol. Nutr. 2016, 63, 291-303. [CrossRef]

98. Mesinovic, J.; Zengin, A.; De Courten, B.; Ebeling, P.R.; Scott, D. Sarcopenia and type 2 diabetes mellitus: A bidirectional relationship. Diabetes Metab. Syndr. Obes. 2019, 12, 1057-1072. [CrossRef] [PubMed]

99. Liccini, A.; Malmstrom, T.K. Frailty and Sarcopenia as Predictors of Adverse Health Outcomes in Persons with Diabetes Mellitus. J. Am. Med. Dir. Assoc. 2016, 17, 846-851. [CrossRef] [PubMed]

100. Sazlina, S.G.; Lee, P.Y.; Chan, Y.M.; Hamid, M.S.; Tan, N.C. The prevalence and factors associated with sarcopenia among community living elderly with type 2 diabetes mellitus in primary care clinics in Malaysia. PLoS ONE 2020, 15, e0233299. [CrossRef] [PubMed]

101. Velázquez-Alva, M.C.; Irigoyen-Camacho, M.E.; Zepeda-Zepeda, M.A.; Lazarevich, I.; Arrieta-Cruz, I.; D’Hyver, C. Sarcopenia, nutritional status and type 2 diabetes mellitus: A cross-sectional study in a group of Mexican women residing in a nursing home. Nutr. Diet. 2020, 77, 515-522. [CrossRef] [PubMed]

102. Okamura, T.; Miki, A.; Hashimoto, Y.; Kaji, A.; Sakai, R.; Osaka, T.; Hamaguchi, M.; Yamazaki, M.; Fukui, M. Shortage of energy intake rather than protein intake is associated with sarcopenia in elderly patients with type 2 diabetes: A cross-sectional study of the KAMOGAWA-DM cohort. J. Diabetes 2019, 11, 477-483. [CrossRef] [PubMed]

103. Stangl, M.K.; Böcker, W.; Chubanov, V.; Ferrari, U.; Fischereder, M.; Gudermann, T.; Hesse, E.; Meinke, P.; Reincke, M.; Reisch, N.; et al. Sarcopenia-Endocrinological and Neurological Aspects. Exp. Clin. Endocrinol. Diabetes 2019, 127, 8-22. [CrossRef]

104. Schiaffino, S.; Dyar, K.A.; Ciciliot, S.; Blaauw, B.; Sandri, M. Mechanisms regulating skeletal muscle growth and atrophy. FEBS J. 2013, 280, 4294-4314. [CrossRef] [PubMed]

105. Pereira, S.; Marliss, E.B.; Morais, J.A.; Chevalier, S.; Gougeon, R. Insulin resistance of protein metabolism in type 2 diabetes. Diabetes 2008, 57, 56-63. [CrossRef] [PubMed]

106. Das, A.K.; Yang, Q.Y.; Fu, X.; Liang, J.F.; Duarte, M.S.; Zhu, M.J.; Trobridge, G.D.; Du, M. AMP-activated protein kinase stimulates myostatin expression in C2C12 cells. Biochem. Biophys. Res. Commun. 2012, 427, 36-40. [CrossRef]

107. Kalyani, R.R.; Tra, Y.; Yeh, H.C.; Egan, J.M.; Ferrucci, L.; Brancati, F.L. Quadriceps strength, quadriceps power, and gait speed in older U.S. adults with diabetes mellitus: Results from the National Health and Nutrition Examination Survey, 1999-2002. J. Am. Geriat.r Soc. 2013, 61, 769-775. [CrossRef] [PubMed]

108. Volpato, S.; Bianchi, L.; Lauretani, F.; Lauretani, F.; Bandinelli, S.; Guralnik, J.M.; Zuliani, G.; Ferrucci, L. Role of muscle mass and muscle quality in the association between diabetes and gait speed. Diabetes Care 2012, 35, 1672-1679. [CrossRef]

109. Oberbach, A.; Bossenz, Y.; Lehmann, S.; Niebauer, J.; Adams, V.; Paschke, R.; Schön, M.R.; Blüher, M.; Punkt, K. Altered fiber distribution and fiber-specific glycolytic and oxidative enzyme activity in skeletal muscle of patients with type 2 diabetes. Diabetes Care 2006, 29, 895-900. [CrossRef]

110. Nezameddin, R.; Itani, L.; Kreidieh, D.; El Masri, D.; Tannir, H.; El Ghoch, M. Understanding Sarcopenic Obesity in Terms of Definition and Health Consequences: A Clinical Review. Curr. Diabetes Rev. 2020, 16, 957-961. [CrossRef]

111. Haus, J.M.; Carrithers, J.A.; Trappe, S.W.; Trappe, T.A. Collagen, cross-linking, and advanced glycation end products in aging human skeletal muscle. J. Appl. Physiol. 2007, 103, 2068-2076. [CrossRef] [PubMed]

112. Mori, H.; Kuroda, A.; Ishizu, M.; Ohishi, M.; Takashi, Y.; Otsuka, Y.; Taniguchi, S.; Tamaki, M.; Kurahashi, K.; Yoshida, S.; et al. Association of accumulated advanced glycation end-products with a high prevalence of sarcopenia and dynapenia in patients with type 2 diabetes. J. Diabetes Investig. 2019, 10, 1332-1340. [CrossRef]

113. Ighodaro, O.M. Molecular pathways associated with oxidative stress in diabetes mellitus. Biomed. Pharmacother. 2018, 108, 656-662. [CrossRef]

114. Tsalamandris, S.; Antonopoulos, A.S.; Oikonomou, E.; Papamikroulis, G.A.; Vogiatzi, G.; Papaioannou, S.; Deftereos, S.; Tousoulis, D. The Role of Inflammation in Diabetes: Current Concepts and Future Perspectives. Eur. Cardiol. 2019, 1, 50-59. [CrossRef] 
115. Yaribeygi, H.; Sathyapalan, T.; Atkin, S.L.; Sahebkar, A. Molecular Mechanisms Linking Oxidative Stress and Diabetes Mellitus. Oxid. Med. Cell. Longev. 2020, 2020, 8609213. [CrossRef]

116. Zhang, P.; Li, T.; Wu, X.; Nice, E.C.; Huang, C.; Zhang, Y. Oxidative stress and diabetes: Antioxidative strategies. Front Med. 2020, 14, 583-600. [CrossRef]

117. Gomes, M.J.; Martinez, P.F.; Pagan, L.U.; Damatto, R.L.; Cezar, M.; Lima, A.; Okoshi, K.; Okoshi, M.P. Skeletal muscle aging: Influence of oxidative stress and physical exercise. Oncotarget 2017, 8, 20428-20440. [CrossRef] [PubMed]

118. Bellanti, F.; Lo Buglio, A.; Vendemiale, G. Chapter 9-Oxidative stress and sarcopenia. Aging 2020, 95-103. [CrossRef]

119. Meng, S.J.; Yu, L.J. Oxidative stress, molecular inflammation and sarcopenia. Int. J. Mol. Sci. 2010, 11, 1509-1526. [CrossRef] [PubMed]

120. Gupta, P.; Aravindhan, A.; Gand, A.; Man, R.; Fenwick, E.K.; Mitchell, P.; Tan, N.; Sabanayagam, C.; Wong, T.Y.; Cheng, C.Y.; et al. Association Between the Severity of Diabetic Retinopathy and Falls in an Asian Population with Diabetes: The Singapore Epidemiology of Eye Diseases Study. JAMA Ophthalmol. 2017, 135, 1410-1416. [CrossRef] [PubMed]

121. Fukuda, T.; Bouchi, R.; Takeuchi, T.; Nakano, Y.; Murakami, M.; Minami, I.; Izumiyama, H.; Hashimoto, K.; Yoshimoto, T.; Ogawa, Y. Association of diabetic retinopathy with both sarcopenia and muscle quality in patients with type 2 diabetes: A cross-sectional study. BMJ Open Diabetes Res. Care 2017, 5, 1-7. [CrossRef]

122. Wang, X.H.; Mitch, W.E. Mechanisms of muscle wasting in chronic kidney disease. Nat. Rev. Nephrol. 2014, 10, 504-516. [CrossRef] [PubMed]

123. Nomura, T.; Ishiguro, T.; Ohira, M.; Ikeda, Y. Diabetic polyneuropathy is a risk factor for decline of lower extremity strength in patients with type 2 diabetes. J. Diabetes Investig. 2018, 9, 186-192. [CrossRef] [PubMed]

124. Parasoglou, P.; Rao, S.; Slade, J.M. Declining Skeletal Muscle Function in Diabetic Peripheral Neuropathy. Clin. Ther. 2017, 6, 1085-1103. [CrossRef]

125. Dziubek, W.; Bulińska, K.; Stefańska, M.; Woźniewski, M.; Kropielnicka, K.; Jasiński, T.; Jasiński, R.; Pilch, U.; Dąbrowska, G.; Skórkowska-Telichowska, K.; et al. Peripheral arterial disease decreases muscle torque and functional walking capacity in elderly. Maturitas 2015, 81, 480-486. [CrossRef]

126. LaMoia, T.E.; Shulman, G.I. Cellular and Molecular Mechanisms of Metformin Action. Endocr Rev 2021, 42, 77-96. [CrossRef]

127. Kristensen, J.M.; Treebak, J.T.; Schjerling, P.; Goodyear, L.; Wojtaszewski, J.F. Two weeks of metformin treatment induces AMPKdependent enhancement of insulin-stimulated glucose uptake in mouse soleus muscle. Am. J. Physiol. Endocrinol. Metab. 2014, 306, E1099-E1109. [CrossRef]

128. Salminen, A.; Kaarniranta, K. AMP-activated protein kinase (AMPK) controls the aging process via an integrated signaling network. Ageing Res. Rev. 2012, 11, 230-241. [CrossRef]

129. Suwa, M.; Egashira, T.; Nakano, H.; Sasaki, H.; Kumagai, S. Metformin increases the PGC-1alpha protein and oxidative enzyme activities possibly via AMPK phosphorylation in skeletal muscle in vivo. J. Appl. Physiol. 2006, 101, 1685-1692. [CrossRef] [PubMed]

130. Nelke, C.; Dziewas, R.; Minnerup, J.; Meuth, S.G.; Ruck, T. Skeletal muscle as potential central link between sarcopenia and immune senescence. EBioMedicine 2019, 49, 381-388. [CrossRef]

131. Kulkarni, A.S.; Brutsaert, E.F.; Anghel, V.; Zhang, K.; Bloomgarden, N.; Pollak, M.; Mar, J.C.; Hawkins, M.; Crandall, J.P.; Barzilai, N. Metformin regulates metabolic and nonmetabolic pathways in skeletal muscle and subcutaneous adipose tissues of older adults. Aging Cell 2018, 17, e12723. [CrossRef]

132. Kwon, B.; Querfurth, H.W. Palmitate activates mTOR/p70S6K through AMPK inhibition and hypophosphorylation of raptor in skeletal muscle cells: Reversal by oleate is similar to metformin. Biochimie 2015, 118, 141-150. [CrossRef] [PubMed]

133. Lebovitz, H.E. Thiazolidinediones: The Forgotten Diabetes Medications. Curr. Diab. Rep. 2019, 19, 151. [CrossRef]

134. Rabøl, R.; Boushel, R.; Almdal, T.; Hansen, C.N.; Ploug, T.; Haugaard, S.B.; Prats, C.; Madsbad, S.; Dela, F. Opposite effects of pioglitazone and rosiglitazone on mitochondrial respiration in skeletal muscle of patients with type 2 diabetes. Diabetes Obes. Metab. 2010, 12, 806-814. [CrossRef] [PubMed]

135. Coletta, D.K.; Sriwijitkamol, A.; Wajcberg, E.; Tantiwong, P.; Li, M.; Prentki, M.; Madiraju, M.; Jenkinson, C.P.; Cersosimo, E.; Musi, N.; et al. Pioglitazone stimulates AMP-activated protein kinase signalling and increases the expression of genes involved in adiponectin signalling, mitochondrial function and fat oxidation in human skeletal muscle in vivo: A randomised trial. Diabetologia 2009, 52, 723-732. [CrossRef] [PubMed]

136. Zeng, Z.; Huang, S.Y.; Sun, T. Pharmacogenomic Studies of Current Antidiabetic Agents and Potential New Drug Targets for Precision Medicine of Diabetes. Diabetes Ther. 2020, 11, 2521-2538. [CrossRef] [PubMed]

137. Tricarico, D.; Mele, A.; Camerino, G.M.; Bottinelli, R.; Brocca, L.; Frigeri, A.; Svelto, M.; George, A.L., Jr.; Camerino, D.C. The KATP channel is a molecular sensor of atrophy in skeletal muscle. J. Physiol. 2010, 588, 773-784. [CrossRef]

138. Gilbert, M.P.; Pratley, R.E. GLP-1 Analogs and DPP-4 Inhibitors in Type 2 Diabetes Therapy: Review of Head-to-Head. Front Endocrinol. 2020, 11, 178. [CrossRef]

139. Giannocco, G.; Oliveira, K.C.; Crajoinas, R.O.; Venturini, G.; Salles, T.A.; Fonseca-Alaniz, M.H.; Maciel, R.M.; Girardi, A.C. Dipeptidyl peptidase IV inhibition upregulates GLUT4 translocation and expression in heart and skeletal muscle of spontaneously hypertensive rats. Eur. J. Pharmacol. 2013, 698, 74-86. [CrossRef] 
140. Sato, H.; Kubota, N.; Kubota, T.; Takamoto, I.; Iwayama, K.; Tokuyama, K.; Moroi, M.; Sugi, K.; Nakaya, K.; Goto, M.; et al. Anagliptin increases insulin-induced skeletal muscle glucose uptake via an NO-dependent mechanism in mice. Diabetologia 2016, 59, 2426-2434. [CrossRef]

141. Takada, S.; Masaki, Y.; Kinugawa, S.; Matsumoto, J.; Furihata, T.; Mizushima, W.; Kadoguchi, T.; Fukushima, A.; Homma, T.; Takahashi, M.; et al. Dipeptidyl peptidase-4 inhibitor improved exercise capacity and mitochondrial biogenesis in mice with heart failure via activation of glucagon-like peptide-1 receptor signalling. Cardiovasc Res. 2016, 111, 338-347. [CrossRef]

142. Rizzo, M.R.; Barbieri, M.; Marfella, R.; Paolisso, G. Reduction of oxidative stress and inflammation by blunting daily acute glucose fluctuations in patients with type 2 diabetes: Role of dipeptidyl peptidase-IV inhibition. Diabetes Care 2012, 35, $2076-2082$. [CrossRef]

143. Nauck, M.A.; Quast, D.R.; Wefers, J.; Meier, J.J. GLP-1 receptor agonists in the treatment of type 2 diabetes-state-of-the-art. Mol. Metab. 2021, 46, 101102. [CrossRef]

144. Green, C.J.; Henriksen, T.I.; Pedersen, B.K.; Solomon, T.P. Glucagon like peptide-1-induced glucose metabolism in differentiated human muscle satellite cells is attenuated by hyperglycemia. PLoS ONE 2012, 7, e44284. [CrossRef]

145. Choung, J.S.; Lee, Y.S.; Jun, H.S. Exendin-4 increases oxygen consumption and thermogenic gene expression in muscle cells. J. Mol. Endocrinol. 2017, 58, 79-90. [CrossRef]

146. Sjøberg, K.A.; Holst, J.J.; Rattigan, S.; Richter, E.A.; Kiens, B. GLP-1 increases microvascular recruitment but not glucose uptake in human and rat skeletal muscle. Am. J. Physiol. Endocrinol. Metab. 2014, 306, E355-E362. [CrossRef]

147. Yamamoto, K.; Amako, M.; Yamamoto, Y.; Tsuchihara, T.; Nukada, H.; Yoshihara, Y.; Arino, H.; Fujita, M.; Uenoyama, M.; Tachibana, S.; et al. Therapeutic effect of exendin-4, a long-acting analogue of glucagon-like peptide-1 receptor agonist, on nerve regeneration after the crush nerve injury. Biomed. Res. Int. 2013, 315848. [CrossRef]

148. Sasaki, T. Sarcopenia, frailty circle and treatment with sodium-glucose cotransporter 2 inhibitors. J. Diabetes Investig. 2019, 10, 193-195. [CrossRef] [PubMed]

149. Merovci, A.; Solis-Herrera, C.; Daniele, G.; Eldor, R.; Fiorentino, T.V.; Tripathy, D.; Xiong, J.; Perez, Z.; Norton, L.; AbdulGhani, M.A.; et al. Dapagliflozin improves muscle insulin sensitivity but enhances endogenous glucose production. J. Clin. Invest. 2014, 124, 509-514. [CrossRef]

150. Bonnet, F.; Scheen, A.J. Effects of SGLT2 inhibitors on systemic and tissue low-grade inflammation: The potential contribution to diabetes complications and cardiovascular disease. Diabetes Metab. 2018, 44, 457-464. [CrossRef] [PubMed]

151. Esterline, R.L.; Vaag, A.; Oscarsson, J.; Vora, J. Mechanisms in endocrinology: SGLT2 inhibitors: Clinical benefits by restoration of normal diurnal metabolism? Eur. J. Endocrinol. 2018, 178, R113-R125. [CrossRef] [PubMed]

152. Dimitriadis, G.; Mitrou, P.; Lambadiari, V.; Maratou, E.; Raptis, S.A. Insulin effects in muscle and adipose tissue. Diabetes Res. Clin. Pract. 2011, 93, S52-S59. [CrossRef]

153. Abdulla, H.; Smith, K.; Atherton, P.J.; Idris, I. Role of insulin in the regulation of human skeletal muscle protein synthesis and breakdown: A systematic review and meta-analysis. Diabetologia 2016, 59, 44-55. [CrossRef] [PubMed]

154. Fujita, S.; Glynn, E.L.; Timmerman, K.L.; Rasmussen, B.B.; Volpi, E. Supraphysiological hyperinsulinaemia is necessary to stimulate skeletal muscle protein anabolism in older adults: Evidence of a true age-related insulin resistance of muscle protein metabolism. Diabetologia 2009, 52, 1889-1898. [CrossRef] [PubMed]

155. Murphy, C.H.; Roche, H.M. Nutrition and physical activity countermeasures for sarcopenia: Time to get personal? Nutr. Bull. 2018, 43, 374-387. [CrossRef] 